\title{
In vitro plant tissue culture: means for production of biological active compounds
}

\author{
Claudia A. Espinosa-Leal ${ }^{1}$. César A. Puente-Garza ${ }^{1}$ · Silverio García-Lara ${ }^{1}$
}

Received: 12 April 2018 / Accepted: 27 April 2018 / Published online: 7 May 2018

(c) Springer-Verlag GmbH Germany, part of Springer Nature 2018

\begin{abstract}
Main conclusion Plant tissue culture as an important tool for the continuous production of active compounds including secondary metabolites and engineered molecules. Novel methods (gene editing, abiotic stress) can improve the technique.
\end{abstract}

Humans have a long history of reliance on plants for a supply of food, shelter and, most importantly, medicine. Current-day pharmaceuticals are typically based on plant-derived metabolites, with new products being discovered constantly. Nevertheless, the consistent and uniform supply of plant pharmaceuticals has often been compromised. One alternative for the production of important plant active compounds is in vitro plant tissue culture, as it assures independence from geographical conditions by eliminating the need to rely on wild plants. Plant transformation also allows the further use of plants for the production of engineered compounds, such as vaccines and multiple pharmaceuticals. This review summarizes the important bioactive compounds currently produced by plant tissue culture and the fundamental methods and plants employed for their production.

Keywords Plant tissue culture $\cdot$ In vitro plant culture $\cdot$ Bioactive $\cdot$ Secondary metabolites $\cdot$ Plant pharmaceuticals .

Transformation

\section{Introduction}

Plant cell and tissue culture uses nutritive culture media and controlled aseptic conditions for the growth of plant cells, tissues and organs. Since its first establishment by Haberlandt in the early twentieth century, this type of culture has evolved into an essential tool for plant research at both the basic and applied levels (Haberlandt 1902). In vitro culture techniques are now indispensable for the production of disease-free plants, rapid multiplication of rare plant genotypes, plant genome transformation, and production of plant-derived metabolites of important commercial value (see Fig. 1) (Debnarh et al. 2006; Altpeter et al. 2016).

Due to the diversity of the methods and applications of available culture techniques, the subject of plant cell/tissue

Silverio García-Lara

sgarcialara@itesm.mx

1 Tecnologico de Monterrey, Campus Monterrey, Escuela de Ingeniería y Ciencias, Ave. Eugenio Garza Sada 2501, 64849 Monterrey, NL, México culture is extensively covered in the existing literature. Some works have even focused on the use of in vitro tissue culture for the production of secondary metabolites (Verpoorte et al. 2000, 2002; Smetanska 2008; Karuppusamy 2009). This work aims to provide an updated overview on the use of in vitro culture for the production of medicinally or commercially important plant metabolites and bioengineered products, nevertheless because of the ample range of information available not all works within the scope of the article could be included, we apologize to those authors. The objective of this review is, therefore, to summarize the main molecules currently being produced using plant cell/ tissue culture, their applications in areas such as medicine and food technology, and the plant material cultured for their production. The review also covers new trends in in vitro cell/tissue culture and plant transformation. 


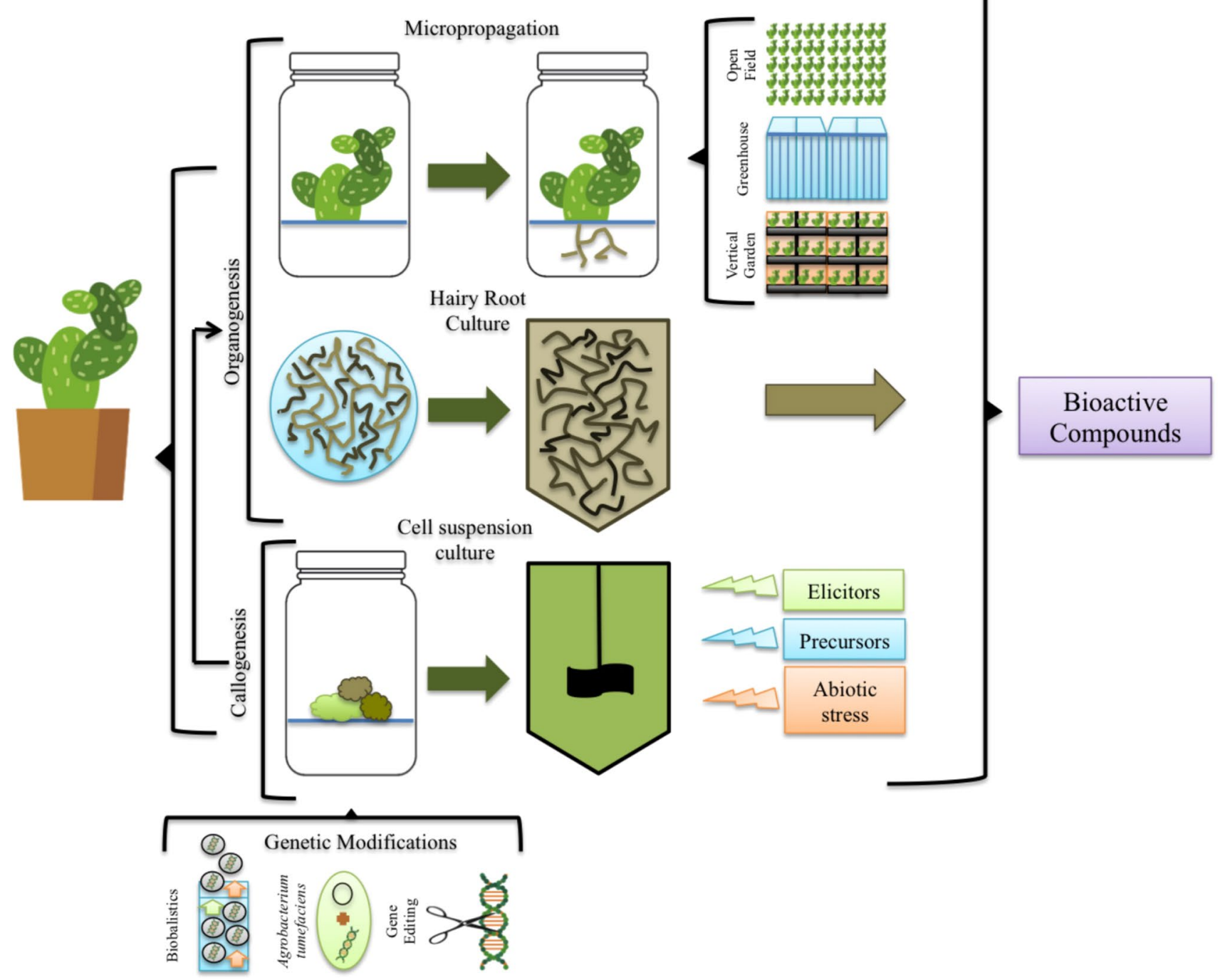

Fig. 1 Diagram of current methods employed for the large-scale production of bioactive compounds using plant in vitro tissue culture

\section{Production of biologically active compounds}

\section{Secondary metabolites}

The term secondary metabolite refers to a compound produced by plants, microorganisms or animals that is not required for their growth (Pickens et al. 2011). Humans have long used the products of plant secondary metabolism to satisfy a multitude of different needs (Borchardt 2002; Patwardhan 2005; Cragg and Newman 2013). The primary use of these compounds has been as medicinal agents, first in an empirical way and subsequently, starting in the 19th century, in a more rational way following the advent of molecule isolation (Corson and Crews 2007; Zenk and Juenger 2007; Cragg and Newman 2013). Despite the extensive research into secondary metabolites over such a long period of time, current estimates indicate that only about $6 \%$ of higher plants (between 300,000 and 500,000 species) have been systematically studied for their pharmacological potential, and only $15 \%$ have been evaluated for phytochemicals in general (Fabricant and Farnsworth 2001; Cragg and Newman 2013). Therefore, enormous opportunities exist for continued studies in this field.

The identification and isolation of a useful bioactive compound immediately generates a need for a method for its continuous production. A secondary metabolite is typically characterized by its diverse and complex chemical structure, usually encompassing multiple chiral centers and labile bonds, and this makes its chemical synthesis challenging (Pickens et al. 2011). Therefore, biologically active molecules are more commonly extracted from their natural sources. However, since most of the source plants 
are wild rather than domesticated species, harvesting from their natural habitats presents a risk of overexploitation, as well as creating a bottleneck in the production of the compounds. Further complications include the slow growth rates of many source plants, the low concentrations of the active compounds of interest and, frequently, the need for biotic or abiotic stress to induce biosynthesis. All these factors make the extraction of secondary metabolites from source species highly inefficient (Atanasov et al. 2015; Ochoa-Villarreal et al. 2016) and emphasize the need for novel approaches for secondary metabolite production.

The in vitro culture of plant cells and tissues under controlled conditions offers a well-founded technology platform for the production of plant natural products. The in vitro propagation (micropropagation) of plants or the in vitro culture of plant organs (usually roots) or callus can typically provide plant material capable of producing secondary metabolites (Atanasov et al. 2015; Morales-Rubio et al. 2016; Ochoa-Villarreal et al. 2016; Espinosa-Leal et al. 2017). Micropropagation has, therefore, become a commercially lucrative enterprise and provides marked advantages over conventional horticultural propagation practices by facilitating the production of large numbers of homogenous plants year-round, the generation of disease-free propagules and a substantial enhancement of multiplication rates (Debnarh et al. 2006). Currently, a large number of protocols are available for the micropropagation of medicinal plants (Debnarh et al. 2006; Rizvi and Kukreja 2010; Sarasan et al. 2011; Kaul et al. 2013; Kun-Hua et al. 2013; Bhattecheryya et al. 2014; Chen et al. 2014a; Atanasov et al. 2015), as well as some commercially important plants, such as Agave salmiana (PuenteGarza et al. 2017a), artichoke (Pandino et al. 2017), Stevia rebaudiana (Ramírez-Mosqueda et al. 2016) and Moringa oleifera (drumstick tree) (Juan-jie et al. 2017). However, the high costs of micropropagation compared with its traditional counterpart (i.e., collection from the wild) and the unpredictability of the needs of the market have limited the use of micropropagation at a commercial level (Debnarh et al. 2006; Methora et al. 2007; Lubbe and Verpoorte 2011; Pence 2011; Sahu and Sahu 2013). Notably, however, recent micropropagation efforts have been aimed at the conservation of overexploited medicinal plants, with special emphasis in plants used for traditional medicines in China and India (Rizvi and Kukreja 2010; Verma et al. 2012; Bhattecheryya et al. 2014; Chen et al. 2016a).

Recent advances in plant cell culture, brought about by the established experience with microbial and animal cell culture, has resulted in effective scale-up from the experimental stage to an industrial scale. Plant cell culture now represents an efficient way to produce several valuable natural products (Fischer et al. 2015). As shown in Table 1, the range of commercially important products includes pigments (e.g., anthocyanins and betacyanins), anti-inflammatory agents (e.g., berberine and rosmarinic acid), and anti-cancer molecules (e.g., paclitaxel and podophyllotoxin).

\section{Plant-made pharmaceuticals and other bioengineered products}

In the early 1990s, transgenic plants were endorsed as an alternative means of production of pharmaceutically important proteins. A transgenic system offers several advantages, including decreased costs, increased ease of delivery and scale-up, decreased risk of contamination with animal and human pathogens, and eukaryotic protein processing. Despite the potential of the method, the past 20 years since its introduction have seen transgenic biomolecules (mostly orally delivered, plant-made vaccines) continue to languish in Phase I of human clinical trials. Only in this current decade has a breakthrough been made, and plant-based products are now geared to proceed to Phase II trials and beyond (Pogue et al. 2010; Thomas et al. 2011).

Table 2 lists the first plant-made human recombinant therapeutic protein approved by regulatory agencies for commercial sale in 2014. Developed by Pfizer, Inc. and Protalix Biotherapeutics, the enzyme taliglucerase alfa (commercially known as ELELYSO-TM) is a treatment for Type 1 Gaucher disease (Pfizer 2014; Pastores et al. 2016). More plant-based products are awaiting approval in one of the phases of clinical trials, and some companies, including Icon Genetics, Ventria Bioscience and Greenovation Biotech, now have the technologies available for the production of several pharmaceuticals derived from plants (see Table 2). This seemingly show growth of the field can be attributed to some of the challenges presented by the method, such as low yields, unwanted glycosylation of products, purification and downstream processing hurdles, and the challenges inherent in the creation of a new manufacturing industry (Tusé et al. 2014; Yao et al. 2015).

Some of these problems can be resolved by judicious selection of the plant material. For instance, the use of maize or lettuce, which are both edible and free of harmful substances, can reduce the need for the intensive purification required for the preparation of parenteral pharmaceuticals, thereby reducing the downstream costs (Hayden et al. 2012, 2014; Lakshmi et al. 2013; Czyz et al. 2014, 2016; Sue et al. 2015). In addition, the appropriate selection of the desired transgenic phenotypes and the use of breeding methods such as backcrossing or inbreeding can lead to the preservation of valuable traits, including high expression of the desired pharmaceutical by the plant material (Pniewski et al. 2017). Other advances have been made in glyco-engineering of host plants, which allows the engineered plants to produce human and mammaliananalogous molecules that exhibit comparable activity to their 


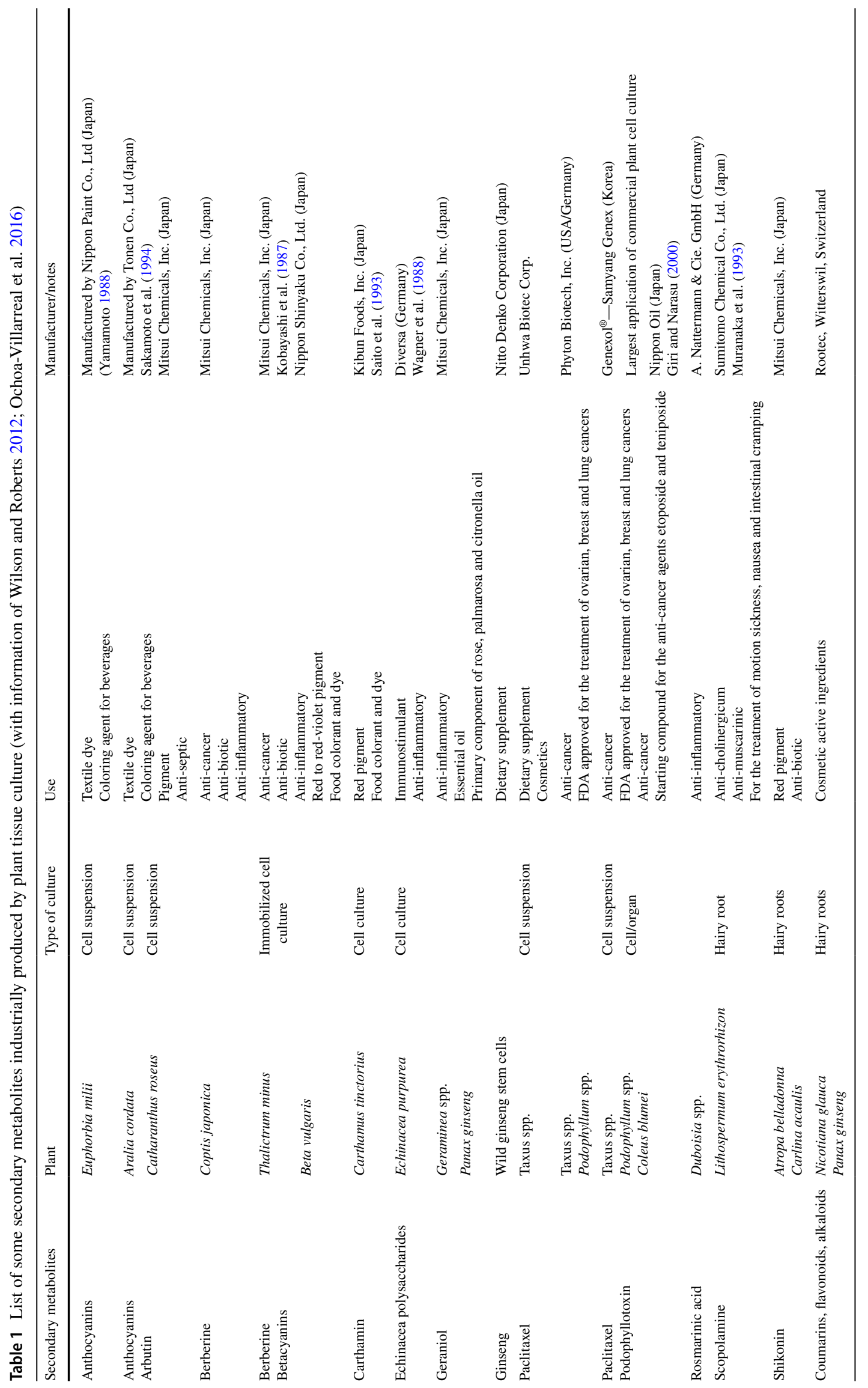




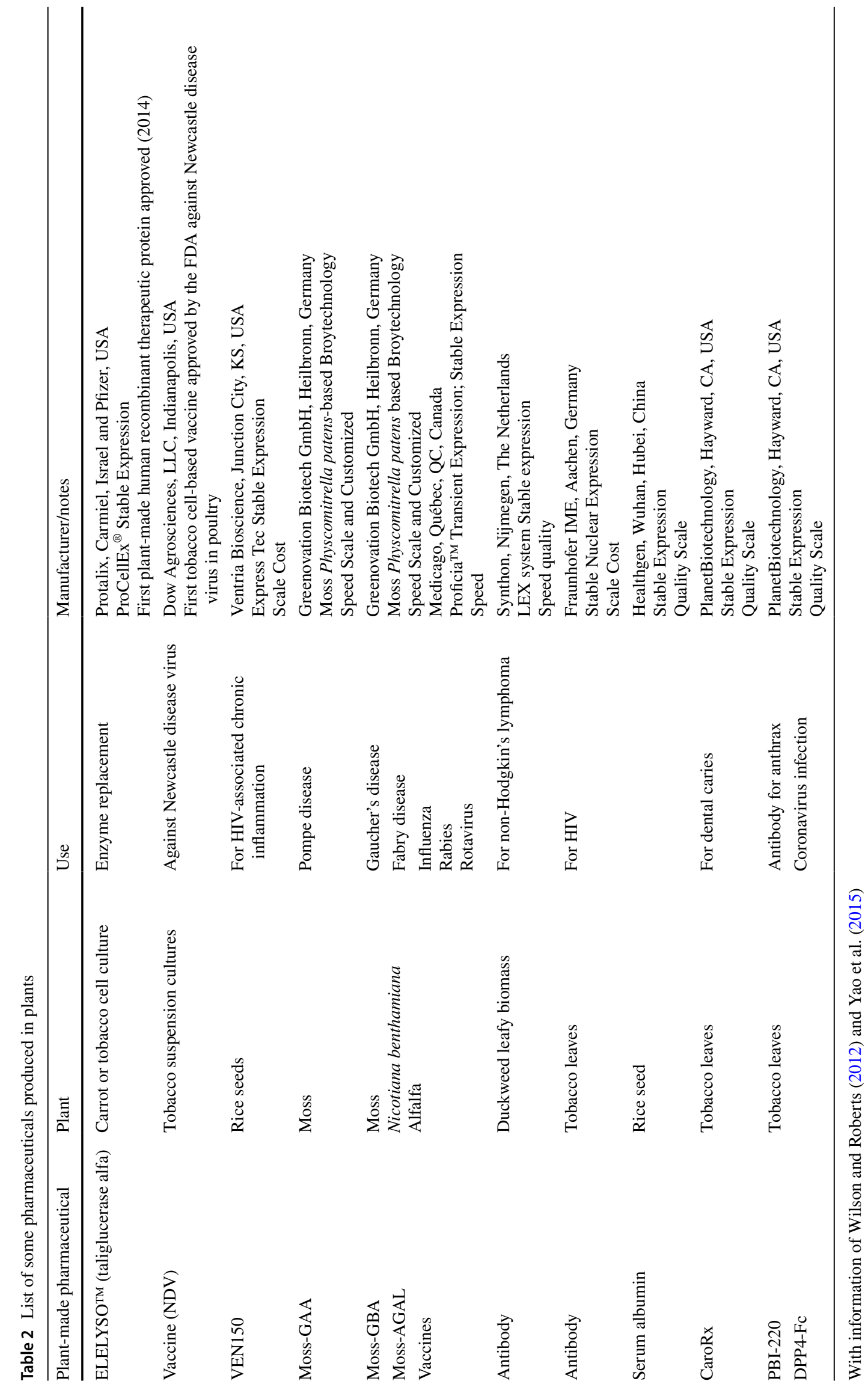


equivalents produced by mammalian cells in culture (Castilho et al. 2011; Zeitlin et al. 2011; Gleba et al. 2014).

Other plant metabolites of interest, which can be bioengineered, are plant growth regulators. These are typically produced in miniscule quantities in plants, but are essential for the regulation of plant cellular processes (Wani et al. 2016). Growth regulators also have critical roles in controlling plant responses to the abiotic stresses, such as drought, salinity and extreme temperatures, factors that limit crop productivity worldwide (Wani and Sah 2014). Due to these characteristics engineered plant growth regulators can be used for the improvement of crops from both nutritional and stress-resistance perspectives (Wani et al. 2016).

\section{Plants employed for the production of biologically active compounds}

An abundance of options, ranging from model plants and crops to wild-type plants, is available when selecting an appropriate plant material for the production of biomolecules. The selection of which plant to use will depend on a number of factors, with the chief considerations being the purpose of the study and the availability of the plant.

Most plants employed for the production of secondary metabolites are non-crop wild types, since these are the plants that already contain the metabolic tools for synthesis of many metabolites of interest (see Table 1). Some examples include Agave salmiana for saponins (PuenteGarza et al. 2017a), Rhaponticoide mykalea for chlorogenic acids (Hayta et al. 2017) and phenolic compounds (Karalija et al. 2017), Leucophyllum frutescens for phenolic compounds (Espinosa-Leal et al. 2015) and Poliomintha glabrescens for luteolin (García-Pérez et al. 2012). All of these compounds are useful in the food, pharmaceutical or cosmetic industries (Perassolo et al. 2017). Other

Table 3 List of in vitro tissue culture steps

\begin{tabular}{|c|c|c|}
\hline Step & Name & Description \\
\hline 0 & Pre-propagation & $\begin{array}{l}\text { Selection of appropriate plant } \\
\text { Pre-treatment of plant }\end{array}$ \\
\hline 1 & Initiation & $\begin{array}{l}\text { Selection of explants (shoot tip, meristem } \\
\text { tip, nodal bud, floral meristem and bud) } \\
\text { Surface sterilization (sodium hypochlo- } \\
\text { rite, ethanol, sterile distilled water, } \\
\text { detergent) }\end{array}$ \\
\hline 2 & Propagation & $\begin{array}{l}\text { Micropropagation: shoot induction } \\
\text { Other: callus of root proliferation }\end{array}$ \\
\hline 3 & Propagation 2 & $\begin{array}{l}\text { Micropropagation: root induction } \\
\text { Other: scale up to bioreactors }\end{array}$ \\
\hline 4 & Hardening & Acclimation to ex vitro conditions \\
\hline
\end{tabular}

With information from Ahloowalia et al. (2003) and Espinosa-Leal et al. (2017) crop plants are used for the production of metabolites such as betalains, which are natural colorants as well as good antioxidants. The main sources of betalain metabolites are the cactus pear (Opuntia ficus-indica) and red beet (Beta vulgaris), and these metabolites are typically produced using hairy roots in bioreactors or by callus culture (Georgiev et al. 2008).

Other crop plants, or their parts, that are used for the production of bioengineered compounds, include carrot cells (enzyme replacement), rice (albumin serum) (both presented in Table 2), maize (vaccines, such as anti-HBV) and lettuce (vaccines and antibodies) (Hayden et al. 2012, 2014; Lakshmi et al. 2013; Czyz et al. 2014, 2016; Su et al. 2015; Yao et al. 2015). Model plants, such as Nicotiana benthamiana, are also transformed for the production of plant pharmaceuticals (Yao et al. 2015), as summarized in Table 2.

\section{Methods of plant tissue culture}

Several methods are available for plant tissue culture; two of the most commonly used are presented in Fig. 1. Organogenesis, which refers to the production of plant organs (roots or shoots), can be accomplished directly from meristems or indirectly from dedifferentiated cells (callus). The resulting cultures can later be used for the massive production of plants (micropropagation) or for the growth of particular organs (i.e., roots in hairy root culture). Callogenesis produces an amorphous mass of cells in response to exposure of explants to different growth regulators. The callus can then be used to regenerate whole plants, or it can be scaled up for the production of important metabolites in cell suspension cultures (Morales-Rubio et al. 2016).

All plant tissue culture methods follow a series of steps, as mentioned in Table 3. First, the plant of interest needs to be selected; this is generally dependent on the aim of the study, but disease- and insect-free plants are preferred; if the plant requires it, some pre-treatments (fungicides and pesticides) can be applied. The next step is the initiation of the in vitro culture. The process requires the excision of small plant pieces (explants) or the use of seeds and their surface sterilization with chemicals. The explants are then

Table 4 List of commonly used culture media used for in vitro plant tissue culture

\begin{tabular}{lll}
\hline Culture media & Salt content $(\mathrm{g} / \mathrm{L})$ & $\begin{array}{l}\text { Nitrogen } \\
\text { content } \\
(\mathrm{mM})\end{array}$ \\
\hline WPM & 2.68 & 14.70 \\
B5 & 3.28 & 26.75 \\
MS & 4.63 & 60.01 \\
\hline
\end{tabular}

With information from Fargoso Monfort et al. (2018) 
placed in appropriate culture media and incubated for a short period of time; contaminated explants are discarded while the surviving ones continue to the next step. The following steps vary depending on the type of culture desired. In organogenesis, this is the propagation phase when explants are cultured on appropriate culture media for shoot or root multiplication, similarly in callogenesis the callus is multiplied. In the next step, callus and root cultures are scaled up for their culture using bioreactors, while the propagated shoots are transferred to root-promoting culture media, in the case of micropropagation. Finally, the micropropagated plants are hardened to grow individual plants capable of photosynthesis. The hardening is done gradually allowing the plants to acclimate to ex vitro conditions. Typically the plants are taken from high to low humidity and from low to high light intensity (Ahloowalia et al. 2003; Espinosa-Leal et al. 2017).

The following sections cover novel developments in plant tissue culture that allow a more efficient production of bioactive compounds.

\section{Improvements in traditional culturing techniques}

Micropropagation has been the technique of choice for the production of whole plants for medicinal, conservation, reforestation and commercial purposes (Afolayan and Adebola 2004; Debnarh et al. 2006; Sarasan et al. 2011). Tissue culture of plants capable of producing important biomolecules offers a number of advantages over traditional field culture, including independence from geographical, seasonal, and environmental variations; uninterrupted production in uniform quality and yield; no need for pesticide and herbicide application; and comparatively short growth cycles (Rao and Ravishankar 2002; Debnarh et al. 2006). Production of secondary metabolites by plant tissue culture depends on a number of factors, chief among them are the nutrients provided for plant growth. The optimum nutrient concentration is a critical determinant in the growth of the explants and the accumulation of secondary metabolites (Rao and Ravishankar, 2002; Nagella and Murthy 2010; Murthy et al. 2014; Fargoso Monfort et al. 2018). The type of culture media used, the salt strength of the medium employed and the growth regulators, type and concentration used, are key factors that most be established for every culture (Rao and Ravishankar, 2002; Fargoso Monfort et al. 2018). The concentration of salts present in the culture media needed by a specific plant varies depending on the particular culture needs. The selection of a suitable medium is essential to establish cell and organ cultures (Nagella and Murthy 2010; Fargoso Monfort et al. 2018). Three of the most popular culture media employed are MS, B5 and WPM, as listed in Table 4. MS basal media contains the highest total salts and nitrogen content. Nitrogen is an essential element that promotes explant growth, since it directly affects amino acid and nucleic acid production in the cells. MS basal media (1962) is the most commonly used plant culture media. As presented in Table 4, it has a very high salt content, nevertheless, it is the preferred medium for the growth of several species (Alvarenga et al. 2015; Grzegorczyk-Karolak et al. 2015; Rahman et al. 2015). It has been demonstrated that different MS salt concentrations influence growth in several species (Assis et al. 2012; Martins et al. 2015; Shekhawat et al. 2015; Singh et al. 2015). Generally, lower salt concentrations stimulate rooting (Sorace et al. 2008; Golle et al. 2012; Shekhawat et al. 2015). Fargoso Monfort et al. (2018) found that in Ocimum basilicum volatile constituents diminished with higher salt concentrations. Plant growth regulators can affect the production of secondary metabolites, a recent review by Jamwal et al. (2018) presents a summary of the production of natural products by using different plant growth regulators.

Nevertheless, one of the principal disadvantages of in vitro tissue culture is the high cost involved with the technique, particularly the expenses associated with culture media (mainly the carbon source, gelling agent and growth regulators), electricity and labor. Some studies have attempted to remedy the cost of culture media using alternative materials, such as household sugar or other sugars, as carbon sources and various types of starches and plant gums instead of agar. Other alternatives have included the use of liquid media and cell-suspension cultures, temporal immersion systems, and reusable glass beads as substitute support matrices (Etienne and Berthouly 2002; Goel et al. 2007; Thorpe 2007; Sahu and Sahu 2013). The cost of electricity can amount up to $60 \%$ of tissue culture production costs. The electrical energy is mostly employed for autoclaving, lighting of the growth room and air filtration in laminar-flow cabinets and air conditioning (Ahloowalia and Savangikar 2003; George and Manuel 2013). The use of artificial lighting in growth rooms is the most expensive and inefficient method on tissue culture technology. It generates heat that needs to be dissipated using air conditioning and it does not match natural light. Additionally, even though plants are capable of adapting to an ample range of conditions, once the adaptation occurs, re-adaptation to new conditions is slow and difficult (Ahloowalia and Savangikar 2003; George and Manuel 2013). The use of natural light is a low-cost option for tissue culture, it reduces electricity and capital costs as well as improves plant quality. There are several ways to achieve this, a simple option is to diffuse natural light under plastic or glass, this works best in temperate climates; some laboratories can be modified to adapt the use of 'solatube' which redirects daylight from rooftops through reflecting tubing (Kodym and Zapata-Arias 1999, 2001; Kodym et al. 2001; Ahloowalia and Savangikar 2003) some laboratories can incorporate southwest facing windows in the growth 
rooms that allow for indirect diffused natural daylight, as is the case of bio-factories in Cuba (Baezas-Lopez 1995; Ahloowalia and Savangikar 2003) and finally some cultures have been successfully propagated using plastic bags as culture containers and hanging them in greenhouses thus eliminating the need of air-conditioned growth rooms (Ahloowalia and Savangikar 2003). Temperature regulation, another high electricity demanding feature of plant in vitro culture, can be mostly avoided since many plants can tolerate wide fluctuations in temperature (Kodym et al. 2001). Labor is another source of high in vitro tissue culture costs. Once the efficiency of labor in transferring number of propagules per hour has been achieved to the maximum possible, there is little room for improvement unless an automated or semiautomated system is implemented. For example, the use of bioreactors and mechanized handling of propagules, such systems have shown to reduce the cost of production by 50\% (Ahloowalia and Savangikar 2003; George and Manuel 2013).

Another problem found in plant tissue culture involves the genetic stability of the plants. Different cases of micropropagation of in vitro-regenerated plants have shown that they are not always clonal copies of the mother plant (Devi et al. 2014; Bhattacharyya et al. 2017a). In vitro culture conditions, especially some growth regulators and elicitors, act as stress factors that induce alterations in sensitive regions of plant genome, and therefore, generate instability in cultured cells, tissues and organs, an occurrence known as somaclonal variation (Larkin and Scowcroft 1981; Gyulai et al. 2003; Bairu et al. 2011; Stanišic et al. 2015; Govindaraju and Arulselvi 2016). The genetic changes experienced by the culture include: alternative DNA methylation, amplification, activation of transposable elements, polyploidy, changes in chromosome number or DNA sequence (Bairu et al. 2011; Stanišic et al. 2015; Govindaraju and Arulselvi 2016). Typically regeneration protocols involving a callus phase are considered the least reliable for clonal propagation, while plantlets regenerated by branching of the axillary buds or direct somatic embryos are considered to be, genetically, the most uniform (Rani and Raina 2000; Varshney et al. 2001; Bhattacharyya et al. 2017b). The occurrence of somaclonal variations during in vitro propagation, industrial production of phytochemicals, or genetically engineered plants can lead to massive economic consequences and represents a serious obstacle in the practical utilization of plant tissue culture techniques for the production of active metabolites (Rahman and Rajora 2001; Bhattacharyya et al. 2016). Therefore, to screen somaclonal variability within a cell culture, it is necessary to monitor and assess the genetic constitution and stability of the in vitro-regenerated plants. The methodologies involved in that process include the use of several techniques to assess possible alterations at different levels (Devarumath et al. 2002; Bhattacharyya et al. 2015, 2017a;
Bose et al. 2016; Bhattacharyya and Van Staden 2016). Flow cytometry and chromosome counting are widely used to assess changes in ploidy and chromosome number; PCRbased DNA markers, random amplified polymorphic DNA (RAPD), random fragmented length polymorphism (RFLP), inter simple sequence repeat (ISSR), amplified fragment length polymorphism (AFLP), microsatellite markers, and start codon targeted (ScoT) polymorphism have been successfully used to evaluate genomic stability of regenerated plants (Hu et al. 2008; Collard and Mackill 2009; Bairu et al. 2011; Singh et al. 2013; Bhattacharyya et al. 2014, 2015; Rathore et al. 2014; Stanišic et al. 2015; Bose et al. 2016; Govindaraju and Arulselvi 2016). An appropriate combination of two or more markers guarantees reliable and efficient testing of genetic fidelity in plants (Palombi and Damiano 2002; Bhattacharyya et al. 2016).

Cell suspension culture remains the best method for the production of active metabolites, especially natural products, with paclitaxel from Taxus spp. being the most prominent example (Atanasov et al. 2015) (Table 1). For the production of cell suspension cultures, the calli are first induced in solid media, the cells are then transferred to liquid media. In small laboratories, the cells are first grown in shaking flasks and later transferred to large-scale liquid-phase bioreactors. There are many different types of reactors including tank reactors, bubble beds and rotary rectors (Furusaki and Takeda 2017). Comprehensive reviews on industrial bioreactors have been published previously and can be consulted for more information on the subject (Su and Lee 2007; Huang and McDonald 2012).

A number of limitations are associated with these methods, when compared with microbial cultures, such as the slow growth rates and low and variable yields of metabolites, and these limitations still restrict the industrial use of plant cell suspension cultures (Kolewe et al. 2008; Kirakosyan et al. 2009). However, the production of important metabolites can be enhanced with modifications to the culture media, such as the addition of elicitors or precursors, or the environmental conditions.

Elicitors stimulate the production of plant natural products that serve as plant defense compounds. Several types of elicitors can increase the secondary metabolite production, including pectin and cellulose (plant cell wall constituents), chitin and glucan (from microorganisms) and salicylic acid and methyl jasmonate (plant immune signaling molecules) (Namdeo 2007; Shilpa et al. 2010; Sharma et al. 2011; Ochoa-Villarreal et al. 2016). Srivastava and Srivastava (2014) used different fungal culture filtrates as biotic elicitors in root cultures of Azadirachta indica to promote the production of Azadirachtin. Filtrates of Curvularia lunata yielded the highest production of the target compound compared to control. Saranya Krishnan and Siril (2018) used yeast extracts, pectin and xylan to elicit the production of 
anthraquinones in Oldenlandia umbellate cultures, with the addition of pectin resulting in the highest elicitation. The selection of the adequate elicitor will depend on the metabolite being produced and the plant culture employed.

Another strategy is to supplement with precursors that are intermediary compounds of the metabolic pathway of the desired natural product. Supplementing the culture media with precursors of secondary metabolites can enhance the yield of the final product (Rao and Ravishankar 2002; Hussain et al. 2012), and has been used successfully in several cases, including the production of phenolic compounds (Palacio et al. 2011), triterpenoids (Chen et al. 2016b) and withanolides (Sivanandhan et al. 2014). Cultures of Antrodia cinnamomea were fed exogenous sterols including squalene, cholesterol, and stigmasterol to enhance their triterpenoid content, the feeding of high doses of stigmasterol resulted in an increased amount of terpens (Chen et al. 2016b). When searching for appropriate precursors it is important to look at the entire biosynthetic pathway and include several molecules involved in different steps of the process, incorporating some examples that affect the production of the target compound in indirect ways. Srivastava and Srivastava (2014) studied the use of precursors to enhance production of azadirachtin including sodium acetate, cholesterol, squalene, isopentenyl pyrophosphate, and others. They found the best results using cholesterol as an indirect precursor. Parra et al. (2017), evaluated the effect of different biochemical precursors in fatty acids production in cacao cell cultures including biotin, pyruvate, acetate and bicarbonate, they also utilized glycerol because it is involved in triglycerides assembly. The later was found to induce a higher fat production compared to the other precursors and control. It is also important to remember that the precursor must be easier and cheaper to acquire the compound of interest.

An alternative way of increasing natural product production is by manipulation of environmental factors. Plants are heavily influenced by environmental factors to regulate the biosynthesis of secondary metabolites, through stress response mechanisms (Zhi-lin et al. 2007; Verma and Shukla 2015). Abiotic stresses related to environmental factors include light intensity, water availability, temperature (high or low), radiation (UV), gaseous toxins (ozone), pesticides and metals (Ni, Cd, Co, Fe, Zn) (Ramakrishna and Ravishankar 2011; Raduisene et al. 2012). Water stress is produced when the plant has limited water availability, either because there is no water (drought) or because the water is dissolving a solute (salinity). Drought stress can be induced in vitro by the addition of high-molecular-weight solutes, such as polyethylene glycol (PEG), to the culture media (Verslues et al. 2006). It has been proven to enhance the production of saponins in A. salmiana (Puente-Garza et al. 2017b), phenolics in Poliomintha glabrescens (García-Pérez et al. 2012) and rosmarinic acid in Salvia miltiorrhiza (Liu et al. 2011). For the induction of salinity stress different concentrations of salts, such as $\mathrm{NaCl}$ and $\mathrm{Na}_{2} \mathrm{CO}_{3}$, can be added to the culture media. This type of stress has resulted in increased production of steviol glycoside content in Stevia rebaudiana (Gupta et al. 2016); Sorbito in Lycopersicon esculentum (Tari et al. 2010) and flavonoids in Hordeum vulgare (Ali and Abbas 2003). Light is an essential abiotic environmental component for plants, since it permits photosynthesis; however, high levels of UV radiation can be harmful (Verma and Shukla 2015). To protect itself form oxidative damage the plant produces several antioxidant metabolites such as polyphenols and tocopherols (Kaur and Kapoor 2001; Argolo et al. 2004). UV radiation can, therefore, be used to enhance the production of secondary metabolites, typically by exposing the cultures to UV light using a special lamp for a set period of time. The technique has been used in Vitis vinifera calli to produce flavonols (Cetin 2014). Different chemicals, including heavy metals, can cause chemical stress. Metal ions influence the production of secondary metabolites, and depending on the plant species and heavy metal type and concentration can even enhance their production (Ramakrishna and Ravishankar 2011; Verma and Shukla 2015; Maleki et al. 2017). As an example is the case of Thalictrum rugosum cell suspension culture that used $\mathrm{CuSO}_{4}$ to stimulate the production of berberine (Kim et al. 1991).

These improvements, however, are not sufficient to sustain an adequate large-scale production of bioactive compounds, so other methods are still needed.

\section{Alternatives to in vitro plant culture}

The low yield of secondary metabolites in cell cultures can be explained as a consequence of a lack of cell differentiation. An alternative strategy to cell culture is the organized culture of roots or shoots (Verporte et al. 2002; Kolewe et al. 2008). Hairy root culture is a perfect example; it is induced by infection of roots with Agrobacterium rhizogenes and the subsequent transfer of the Ri plasmid, which induces abundant growth of neoplastic roots that can be maintained in vitro (Ron et al. 2014). Grzegorczyk-Karolak et al. (2018) obtained hairy root culture of Salvia viridis by wounding shoot explants with needles dipped in Agrobacterium rhizogenes strain A4 culture. Some of the advantages provided by hairy root cultures include high growth rates without the need for plant growth regulators, genetically and biochemically stable cultures, and a similar capacity for production of secondary metabolites than cell suspension cultures (Guillon et al. 2006; Georgiev et al. 2012; Mora-Pale et al. 2014). A wide range of natural products has been produced using this system, including lignans, steroids, anthraquinones and alkaloids (Doma et al. 2012; Huang et al. 2014; Pandey et al. 2014; Wawrosch et al. 2014). However, metabolite 
production requires that the compound of interest be one that is normally synthesized within the roots of the source plant, so this limits the versatility of the hairy root system (Ochoa-Villarreal et al. 2016).

Nevertheless, the greatest limiting factor in the industrial use of hairy rots for the production of secondary metabolites is their scale-up, since it requires the development of appropriate culture vessels that permit mixing without causing shear damage to the interconnected root mat. Binoy et al. (2016) designed a novel culture vessel by customizing a reaction kettle ( $2 \mathrm{~L}$ ) for the culture of Plumbago rosea and production of plumbagin an anticancer molecule. Srivastava and Srivastava (2007) described the different configurations and parameters of bioreactors for hairy roots culture, which include liquid phase, gas phase and hybrid systems. ROOT Bioactives AG, a Swiss company, has successfully developed and optimized a bioreactor system for large-scale cultivation of hairy roots capable of producing many kinds of bioactive compounds, including secondary metabolites and recombinant glycosylated proteins with pharmaceutical properties (Atanasov et al. 2015; Ochoa-Villarreal et al. 2016). However, many factors influence the scale-up process, such as culture medium properties, hormonal balance, gaseous composition, growth kinetics, inoculum density, culture period, and the species (Ho et al. 2017). In the scaleup process, Ho et al. (2017) recently obtained a 4.01-kg dry root biomass with a yield of $287.12 \mathrm{mg} / \mathrm{L}$ of total phenolic productivity for Polygonum multiflorum in a 500 L pilotscale reactor. Hybrid systems, which include a liquid- and a gas phase, are reactors that attend the disadvantage of the null distribution uniformity of cells in gas-phase reactors, and the limitations of the mass transfer in liquid-phase reactors; these systems offer the best compromise between the two systems, used in alternate way (Srivastava and Srivastava 2007). Biomass measurement is one of the major challenges during scale-up of hairy roots culture, however, it is also important to determine the harvest capacity of secondary metabolites and their bioactivity, some examples are phenolic compounds (Ho et al. 2017; Thiruvengadam et al. 2014), xanthones (Vinterhalter et al. 2015), glucosinolates (Chung et al. 2016), tetraterpenoids (Thakore and Srivastava 2017), among others.

Transformed hairy roots have shown a higher biological activity, compared with non-transformed roots (Chung et al. 2016; Jeong et al. 2005; Vinterhalter et al. 2015). However, it is important to determine the optimal number of subcultures to avoid somaclonal variations that can affect the yield and behavior of plant cell cultures (Martínez-Estrada et al. 2017). Additionally, hairy root culture is susceptible to the use of biotic and abiotic elicitors to enhance the production of the desired metabolites, like the examples presented above from Srivastava and Strivastava (Srivastava and Srivastava 2014). Furthermore, a combined approach using both types of elicitors can be employed. For instance Wang et al. (2016) used ultraviolet-B (UV-B) radiation and methyl jasmonate applied alone or in combination in Salvia miltiorrhiza hairy root cultures and found that the combined treatment exhibited synergistic effects on the expression levels of genes in the tanshinone biosynthetic pathway.

Another way to avoid some of the major difficulties encountered when using cell cultures, such as variability in product biosynthesis, large cell aggregates and shear stress (Yun et al. 2012), is to use cultures of undifferentiated cambial meristematic cells. These cultures are not only free of the problems stated above, but the cells are physiologically stable and show high growth rates (Lee et al. 2010; Jang et al. 2012). Cambial meristematic cells are undifferentiated cells that grow indefinitely, behaving like plant stem cells (Lee et al. 2010; Ochoa-Villarreal et al. 2016). They eliminate the need for dedifferentiating plant cells for the establishment of plant cell cultures, and they offer greater stability in product accumulation over long periods (Lee et al. 2010). This type of culture has been established for the production of nutritional, cosmetic and medicinal products and is currently considered a key platform for the large-scale production of natural products (Roberts and Kolewe 2010; Yun et al. 2012; Ochoa-Villarreal et al. 2016).

Plant cell cultures rarely present uniform physiological characteristics, most especially callus cultures. Their heterogeneous nature results in the need to select highly productive cell lines to establish profitable production platforms for natural products (Mulabagal and Tsay 2004; Ochoa-Villarreal et al. 2016). A novel cell line can be obtained by employing cell-cloning methods. First, since accumulation of active metabolites is genotype specific, an appropriate selection of suitable species and later organs for callus production is needed (Murthy et al. 2014; Ochoa-Villarreal et al. 2016). The selection process depends on the type of compound intended to produce, if the product of interest is a pigment a spectrophotometric method can be employed, however, if it is not other chemical-based approaches are needed (Fujita et al. 1984; Mulabagal and Tsay 2004; Ochoa-Villarreal et al. 2016). A popular method involves the identification of cell lines that exhibit a high level of metabolic flux through the targeted pathway by the exogenous application of an intermediate (Ochoa-Villarreal et al. 2016). For example, high producing shoots of Mentha arvensis were screened by adding menthol to the culture media. The surviving clones exhibited high menthol tolerance, thus presenting genotypes capable of elevated menthol production (Dhawan et al. 2003). Nevertheless, the prolonged use of selected natural product producing cell lines is limited, since they often loose their ability to produce the desired metabolites (Georgiev et al. 2009; Wilson and Roberts 2012; Ochoa-Villarreal et al. 2016). The cell lines decrease or loss of active compound biosynthesis is due, in most cases, to genetic instability 
resulting from somaclonal variations (Ochoa-Villarreal et al. 2016).

Despite the problems presented above, there are some commercially available plant cell lines currently in the market. The most popular is Tobacco Bright Yellow-2 cells (BY-2), they are attractive because of their fast growth rate and their ease of Agrobacterium-mediated transformation and cell cycle synchronization (Su and Lee 2007). Additionally, the Leibniz Institute DSMZ-German Collection of Microorganisms and Cell Cultures have an ample catalog of plant cell lines. They offer 41-plant cell lines, 18 of which are delivered as actively growing cultures and 23 are maintained as cryopreserved cultures. Among the plants offered are some model plants like Solanum tuberosum and Arabidopsis thaliana and some medicinal plants like Echinacea angustifolia, Arnica montana and Valeriana officinalis (Leibniz Gemeinschaft 2018). Acquisition of the cell lines would facilitate the establishment of the culture and allow for a more streamline process of plant transformation and metabolite production.

\section{Strategies for the expression of plant biologically active compounds}

Low expression levels of plant active metabolites and expression of new important compounds not typically expressed in plants, such as vaccines, create a need for tools that allow the modification of plant genetic material. Plant genetic engineering has been practiced since the 1980s, first with Agrobacterium and later with transformation mediated by particle bombardment. Both techniques have been effective for an array of plants, allowing over-expression of secondary metabolites or the production of plant-made pharmaceuticals. Nevertheless, despite this success, these methods present several challenges that limit their use in many crops (Altpeter et al. 2016).

Agrobacterium-mediated transformation can be performed in most dicotyledonous (dicot) plants (however, it is mostly limited to some genotypes within a species) and in a small number of monocotyledonous (monocot) plants (Klee et al. 1987; Nam et al. 1997). Problems arising from the use of A. tumefaciens for plant transformation include difficulties obtaining licensing (Chi-Ham et al. 2012), high costs of securing regulatory approval, and plant innate responses to bacterial infection, such as the activation of some proteins that cause tissue browning and necrosis that, in turn, reduce transformation frequencies (Altpeter et al. 2016). Some of these difficulties can be easily avoided with small modifications to the technique, like downregulating infection-responsive genes in the host plants or adding antioxidants to the infection medium (Altpeter et al. 2016).
To eliminate the rest of the problems, researchers continue to seek out a novel gene delivery system based on a non-pathogenic organism that will provide high rates of transformation for both dicot and monocot species. Advances have been made with several species of Rhizobium (Sinorhizobium meliloti, Mesorhizobium loti and NGR 234) known as Transbacter (Zuniga-Soto et al. 2015). Another gram-negative bacterial member of the Rhizobiaceae family, Ensifer adhaerens strain OV14, unlike A. tumefaciens, also seems to be beneficial to plants and has been used successfully for the transformation of Arabidopsis thaliana, Solanum tuberosum and Oryza sativa L. (Martin 2002; Wendt et al. 2012; Zhou et al. 2013).

Bioballistics can be used on a wider range of plant genotypes than are amenable to Agrobacterium transformation. This technique lacks the pathogenic characteristic of the bacteria and simplifies the cloning process since it does not require a specific vector (Chen et al. 2014b; Altpeter et al. 2016). However, plant tissues subjected to this technique often show difficulties in regeneration after bombardment and in the transgene performance. The effectiveness seems to depend on particle characteristics, such as type, size, quantity and acceleration; on the DNA amount and structure; and on the tissue type and pretreatment (Zuniga-Soto et al. 2015). Advancements in these techniques could potentially enhance the regeneration and transformation responses of a wide range of plants of economic interest (Zuniga-Soto et al. 2015).

Genome editing mediated by CRISPR/Cas9, a new development in plant genome transformation, may be a promising solution to most of the problems of the currently available techniques. This new technology allows modification of specific areas of the genome with an increased precision of the insertion, while preventing cell toxicity and offering perfect reproducibility (Voytas 2013; Voytas and Gao 2014). Genome editing is currently applied in one of three forms: (1) Alteration of a small number of nucleotides, (2) replacement of an allele with a pre-existing one, and (3) insertion of new genes in predetermined regions of the genome (Abdallah et al. 2015). Since genome editing techniques create only small traces of DNA alterations, most regulatory procedures associated with transgenic plants are avoided and the technique can be employed for the rapid creation of new crops with pest resistance, enhanced nutritional value and drought tolerance (Voytas 2013; Abdallah et al. 2015; Li et al. 2015). Some successful examples include transformations of solanaceous crop plants like potato and tomato (Van Eck 2018), soybean ( $\mathrm{Li}$ et al. 2015) and some cereals, such as barley, maize, rice, wheat and sorghum (Zhu et al. 2017). 


\section{Perspectives for plant production of bioactive molecules}

In vitro tissue culture is a vital tool that can be employed for the rapid production of important metabolites. Once a commercially important compound has been identified and isolated, measures can be taken for its scale-up production, as shown in Fig. 1. Currently, several systems, such as suspension cultures and hairy roots, allow for the large-scale manufacture of plant compounds (Fig. 1) (Xu et al. 2012). Nevertheless, as mentioned earlier, the high costs associated with this technology makes it uncompetitive when compared to less expensive but environmentally unsustainable processes such as collection of wild plants or when compared to chemical synthesis. These culture methods also still require the use of sterilizable bioreactors, so their scale-up is limited (Nogueira et al. 2018; Buyel et al. 2017).

The advent of novel molecular tools now presents new possibilities for the production of important metabolites using plant systems. Chief among these is the use of targeted genome engineering, particularly the previously mentioned genome editing mediated by CRISPR/ Cas9. The use of this technological approach creates the possibility of producing new plant varieties without the introduction of foreign genes (Doudna and Charpentier 2014; Baltes and Voytas 2015; Nogueira et al. 2018). Gene editing could potentially be used for the introduction of new alleles, promoter replacement or the introduction of new pathways, all of which could result in the creation of plant-based systems capable of novel expression of useful bioactive molecules (Nogueira et al. 2018).

Once the plant has been engineered (either by gene editing by CRISPR/Cas9 or by traditional methods), and has passed through in vitro culture, the genetic material can be stored using master and working seed banks (Sack et al. 2015). The plants can then be used for the large-scale production of the desired metabolites, including plant-made pharmaceuticals. Three options are available for the cultivation of the engineered plants: under open-field conditions, if legal, in conventional greenhouses or in vertical farming units, as modeled in Fig. 1, with the latter two offering ease of scale-up and appropriate containment of the plants (Buyel et al. 2017).

Some plants, like medicinal plants, benefit from in vitro conditions (faster growth rates) and should, therefore, be sustained in those settings (Rao and Ravishankar 2002). With this in mind, several actions can increase the production of secondary metabolites by plant cells (Fig. 1); some of these, like the use of precursors and elicitors, have already been mentioned. The manipulation of environmental factors, including high/low temperature, drought, UV, alkalinity, salinity, exposure to heavy metals, and others, is now emphasized. These conditions, which are potentially damaging to the plants, often increase the capacity for production or even induce de novo synthesis of secondary metabolites in plant in vitro cultures (Korkina et al. 2017; Lajayer et al. 2017; Moon et al. 2017; Puente-Garza et al. 2017b).

\section{Conclusions}

The use of in vitro tissue culture remains a feasible strategy for the production of structurally complex and high-value natural products, especially if the plant source material is an overexploited, slow-growing or low-yielding plant. However, due to the higher costs, a cost-benefit analysis of in vitro culture is wise before implementation of the technique. Similarly, the production of pharmaceuticals using plant culture systems can offer significant advantages, including reduction in costs, rapid production, low burden of human pathogens and scalability; all these advantages are plant product specific and depend on the production efficiencies compared to those offered by alternative sources. In the next decade, tissue culture should reach its full potential with the use of novel technologies such as gene editing and environmental factor manipulation.

Author contribution statement All authors contributed equally to this work in terms of writing and conception. All authors wrote and reviewed the latest version of this manuscript.

Acknowledgements The Research Nutriomics Chair Funds and CAT005 from Tecnologico de Monterrey, Escuela de Ingeniería y Ciencias, as well as Postdoctoral fellowships presented to Dr. Claudia EspinosaLeal by Consejo Nacional de Ciencia y Tecnología (CONACyT), Mexico and Tecnologico de Monterrey supported this research.

\section{Compliance with ethical standards}

Conflict of interest The authors declare that the research was conducted in the absence of any commercial or financial relationships that could be construed as a potential conflict of interest.

\section{References}

Abdallah NA, Prakash CS, McHughen AG (2015) Genome editing for crop improvement: challenges and opportunities. GM Crops Food 6:183-205. https://doi.org/10.1080/21645698.2015.1129937

Afolayan AJ, Adebola PO (2004) In vitro propagation: a biotechnological tool capable of solving the problem of medicinal plants decimation in South Africa. Afr J Biotechnol 3:683-687

Ahloowalia BS, Savangikar VA (2003) Low cost options for energy and labour. Low cost options for tissue culture technology in 
developing countries. In: Proceedings of a technical meeting organized by the Joint FAO/IAEA Division of Nuclear Techniques in Food and Agriculture and held in Vienna, 26-30 August 2002 (pp. 41-46). Viennam Austria: International Atomic Energy Agency. ISBN 92-0-115903-X

Ahloowalia BS, Prakash J, Savangikar VA, Savangikar C (2003) Plant tissue culture. Low cost options for tissue culture technology in developing countries. In: Proceedings of a technical meeting organized by the Joint FAO/IAEA Division of Nuclear Techniques in Food and Agriculture and held in Vienna, 26-30 August 2002 (pp. 3-10). Vienna, Austria: International Atomic Energy Agency. ISBN 92-0-115903-X

Ali RM, Abbas HM (2003) Response of salt stressed barley seedlings to phenylurea. Plant Soil Environ 49:158-162

Altpeter F, Springer NM, Bartley LE, Blechl AE, Brutnell TP, Citovsky V, Conrad L, Gelvin SB, Jackson D, Kausch AP, Lemaux PG, Medford JI, Orozco-Cardenas M, Tricoli D, VanEck J, Voytas DF, Walbot V, Wang K, Zhang ZJ, Stewart CN (2016) Advancing crop transformation in the era of genome editing. Plant Cell 28:1510-1520. https://doi.org/10.1105/tpc.16.00196

Alvarenga IA, Pacheco FV, Silva ST, Bertolucci SV, Pinto JB (2015) In vitro culture of Achillea millefolium L.: quality and intensity of light on growth and production of volatiles. Plant Cell Tissue Organ Cult 122:299-308. https://doi.org/10.1007/s11240-015-0766-7

Argolo AC, Sant'Ana AE, Pletsch M, Coelho LC (2004) Antioxidant activity of leaf extracts from Bauhinia monandra. Bioresour Technol 95:229-233. https://doi.org/10.1016/j.biort ech.2003.12.014

Assis KC, Pereira FD, Cabral JS, Silva FG, Silva JW, Santos SC (2012) In vitro cultivation of Anacardium othonianum Rizz.: effects of salt concentration and culture medium volume. Acta Sci Agron 34:77-83. https://doi.org/10.4025/actasciagron.v34i1.10984

Atanasov AG, Waltenberger B, Pferschy-Wenzig AM, Linder T, Wawrosch C, Uhrin P, Temml V, Wang L, Schwaiger S, Heiss EH, Rollinger JM, Schuster D, Breuss JM, Bochkov V, Mihovilovic MD, Kopp B, Bauer R, Dirsch VM, Stuppner H (2015) Discovery and resupply of pharmacologically active plant-derived natural products: a review. Biotechnol Adv 33:1582-1614. https ://doi.org/10.1016/j.biotechadv.2015.08.001

Baezas-Lopez P (1995) Cubans enlist the sun in virus-free propagation. Ceres 156:15-16

Bairu MW, Aremu AO, Van Staden J (2011) Somaclonal variation in plants: causes and detection methods. Plant Growth Regul 63:147-173. https://doi.org/10.1007/s10725-010-9554-x

Baltes NJ, Voytas DF (2015) Enabling plants synthetic biology through genome engineering. Trends Biotechnol 33:120-131. https://doi. org/10.1016/j.tibtech.2014.11.008

Bhattacharyya P, Van Staden J (2016) Ansellia africana (Leopard orchid): a medicinal or- chid species with untapped reserves of important biomolecules—a mini review. S Afr J Bot 106:181185. https://doi.org/10.1016/j.sajb.2016.06.010

Bhattacharyya P, Kumaria S, Job N, Tandon P (2015) Phyto-molecular profiling and assessment of antioxidant activity within micropropagated plants of Dendrobium thyrsiflorum: a threatened, medicinal orchid. Plant Cell Tissue Organ Cult 122:535-550. https://doi.org/10.1007/s11240-015-0818-z

Bhattacharyya P, Kumaria S, Job N, Tandon P (2016) En-masse production of elite clones of Dendrobium crepidatum: a threatened, medicinal orchid used in Traditional Chinese Medicine (TCM). J Appl Res Med Aromat Plants 3:168-176. https://doi. org/10.1016/j.jarmap.2016.04.001

Bhattacharyya P, Kumar V, Van Staden J (2017a) Assessment of genetic stability amongst micropropagated Ansellia africana, a vulnerable medicinal orchid species of Africa using SCoT markers. S Afr J Bot 108:294-302. https://doi.org/10.1016/j. sajb.2016.11.007
Bhattacharyya P, Kumaria S, Bose B, Paul P, Tandon P (2017b) Evaluation of genetic stability and analysis of phytomedicinal potential in micropropagated plants of Rumex nepalensis - a medicinally important source of pharmaceutical biomolecules. J Appl Res Med Aromat Plants 6:80-91. https://doi.org/10.1016/j.jarma p.2017.02.003

Bhattecheryya P, Kumaria S, Diengdoh R, Tandon P (2014) Genetic stability and phytochemical analysis of the in vitro regenerated plants of Dendrobium nobile Lindl., an endangered medicinal orchid. Meta Gene 2:489-504. https://doi.org/10.1016/j.mgene .2014.06.003

Binoy J, Silja PK, Dhanya B, Pillai B, Satheeshkumar K (2016) In vitro cultivation of hairy roots of Plumbago rosea $\mathrm{L}$. in a customized reaction kettle for the production of plumbagin—an anticancer compound. Ind Crops Prod 87:89-95. https://doi.org/10.1016/j. indcrop.2016.04.023

Borchardt JK (2002) The beginnings of drug therapy: ancient Mesopotamian medicine. Drug News Prespect 15:187-192

Bose B, Kumaria S, Choudhury H, Tandon P (2016) Assessment of genetic homogeneity and analysis of phytomedicinal potential in micropropagated plants of Nardostachys jatamansi a critically endangered, medicinal plant of alpine Himalayas. Plant Cell Tissue Organ Cult 2:331-349. https://doi.org/10.1007/s1124 0-015-0897-x

Buyel JF, Twyman RM, Fischer R (2017) Very-large-scale production of antibodies in plants: the biologization of manufacturing. Biotechnol Adv 35:458-465. https://doi.org/10.1016/j.biotechadv .2017.03.011

Castilho A, Gattinger P, Grass J, Jez J, Pabst M, Altmann F et al (2011) $\mathrm{N}$-Glycosylation engineering of plants for the biosynthesis of glycoproteins with bisected and branched complex N-glycans. Glycobiology 21:813-823. https://doi.org/10.1093/glycob/cwr00 9

Cetin ES (2014) Induction of secondary metabolite production by UV-C radiation in Vitis vinifera L. Öküzgözü callus cultures. Biol Res 47:37. https://doi.org/10.1186/0717-6287-47-37

Chen C-C, Chang C-L, Agrawal DC, Wu C-R, Tsay H-S (2014a) In vitro propagation and analysis of secondary metabolites in Glossogyne tenuifolia (Hsiang-Ju)—a medicinal plant native to Taiwan. Bot Stud 55:45. https://doi.org/10.1186/s4052 9-014-0045-7

Chen Q, Lai H, Hurtado J, Stahnke J, Leuzinger K, Dent M (2014b) Agroinfiltration as an effective and scalable strategy of gene delivery for production of pharmaceutical proteins. Adv Tech Biol Med 1:1-21. https://doi.org/10.4172/atbm.1000103

Chen S-L, Yu H, Luo H-M, Wu Q, Li C-F, Steinmetz A (2016a) Conservation and sustainable use of medicinal plants: problems, progress and prospects. Chin Med 11:1-10. https://doi.org/10.1186/ s13020-016-0108-7

Chen Y-T, Shen Y-C, Chang M-C, Lu M-K (2016b) Precursor-feeding strategy on the triterpenoid production and anti-inflammatory activity of Antrodia cinnamomea. Process Biochem 51:941-949. https://doi.org/10.1016/j.procbio.2016.05.001

Chi-Ham CL, Boettiger S, Figueroa-Balderas R, Bird S, Geoola JN, Zamora P, Alandete-Saez M, Bennett AB (2012) An intellectual property charing initiative in agricultural biotechnology: development of broadly accessible technologies for plant transformation. Plant Biotechnol J 10:501-510. https://doi.org/10.11 11/j.1467-7652.2011.00674.x

Chung IM, Rekha K, Rajakumar G, Thiruvengadam M (2016) Production of glucosinolates, phenolic compounds and associated gene expression profiles of hairy root cultures in turnip (Brassica rapa ssp. rapa). 3 Biotech 6:175. https://doi.org/10.1007/s1320 5-016-0492-9

Collard BC, Mackill DJ (2009) Start codon targeted (SCoT) polymorphism: a simple, novel DNA marker technique for generating 
gene-targeted markers in plants. Plant Mol Biol Rep 27:86-93. https://doi.org/10.1007/s11105-008-0060-5

Corson TW, Crews CM (2007) Molecular understanding and modern application of traditional medicines: triumphs and trials. Cell 130:769-774. https://doi.org/10.1016/j.cell.2007.08.021

Cragg GM, Newman DJ (2013) Natural products: a continuing source of novel drug leads. Biochim Biophys Acta 1830:3670-3695. https://doi.org/10.1016/j.bbagen.2013.02.008

Czyz M, Dembczynski R, Marecik R, Wojas-Turek J, Milczarek M, Pajtasz-Piasecka E, Wietrzyk J, Pniewski T (2014) Freezedrying of plant tissue containing HBV surface antigen for the oral vaccine againts hepatitis B. Biomed Res Int. https://doi. org/10.1155/2014/485689

Czyz M, Dembczynski R, Marecik R, Pniewski T (2016) Stability of $\mathrm{S}$-HBsAg in long-term stored lyophilised plant tissue. Biologicals 44:69-72. https://doi.org/10.1016/j.biologicals.2015.12.001

Debnarh M, Malik CP, Baisen PS (2006) Micropropagation:a tool for the production of high quality plant based medicines. Curr Pharm Biotechnol 7:33-49

Devarumath R, Nandy S, Rani V, Marimuthu S, Muraleedharan N, Raina S (2002) RAPD, ISSR and RFLP fingerprints as useful markers to evaluate genetic integrity of micropropagated plants of three diploid and triploid elite tea clones representing Camellia sinensis (China type) and C. assamica ssp. assamica (AssamIndia type). Plant Cell Rep 21:166-173. https://doi.org/10.1007/ s00299-002-0496-2

Devi SP, Kumaria S, Rao SR, Tandon P (2014) Single primer amplification reaction (SPAR) methods reveal subsequent increase in genetic variations in micropropagated plants of Nepenthes khasiana Hook. $f$. maintained for three consecutive regenerations. Gene 538:23-29. https://doi.org/10.1016/j.gene.2014.01.028

Dhawan S, Shasany AK, Naqvi AA, Kumar S, Suman PS (2003) Menthol tolerant clones of Mentha arvensis: approach for in vitro selection of menthol rich genotypes. Plant Cell Tissue Organ Cult 75:87-94. https://doi.org/10.1023/A:1024684605967

Doma M, Abhayankar G, Reddy VD, Kavi Kishor PB (2012) Carbohydrate and elicitor enhanced withanolide (withatefin $\mathrm{A}$ and withanolide A) accumulation in hairy root cultures of Withania smnifera (L.). Indian J Exp Biol 50:484-490

Doudna JA, Charpentier E (2014) The new frontier of genome engineering with CRISPR-Cas9. Scinece 1077. https://doi. org/10.1126/science.1258096

Espinosa-Leal C, Treviño-Neávez JF, Garza-Padrón RA, Verde-Star MJ, Rivas-Morales C, Morales-Rubio ME (2015) Total phenols and anti-radical activity of methanolic extracts from wild and in vitro conditions of Leucophyllum frutescens. Rev Mex Cienc Farm 46:52-56

Espinosa-Leal CA, Garza-Padrón RA, Morales-Rubio ME (2017) Cultivo in vitro como alternativa para la producción de metabolitos. Editorial Académica Española, Saarbrücken

Etienne H, Berthouly M (2002) Temporary immersion systems in plant micropropagation. Plant Cell Tissue Organ Cult 69:215-231

Fabricant DS, Farnsworth NR (2001) The value of plants used in traditional medicine for drug discovery. Environ Health Perspect 109(supplement):69-75

Fargoso Monfort LE, Vilela Bertolucci SK, Fabri Lima A, Alves de Carvalho A, Mohammed A, Fitzgerard Blank A, Pereira Pinto JEB (2018) Effects of plant growth regulators, different culture media and strength MS on production of volatile fraction composition in shoot cultures of Ocimum basilicum. Ind Crops Prod 116:231-239. https://doi.org/10.1016/j.indcrop.2018.02.075

Fischer R, Vasilev N, Twyman RM, Schillberg S (2015) High-value products from plants: the challenges of process optimization. Curr Opin Biotechnol 32:156-162. https://doi.org/10.1016/j. copbio.2014.12.018
Fujita Y, Takahashi S, Yamada Y (1984) Selection of cell lines with high productivity of shikonin derivatives through protoplasts of Lithospermum erithrorhizon. Proc Eur Congr Biotechnol 1:161166. https://doi.org/10.1271/bbb1961.49.1755

Furusaki S, Takeda T (2017) Bioreactors for plant cell culture, reference module in life sciences. Elsevier, Dordrecht. https://doi. org/10.1016/b978-0-12-809633-8.09076-2 (Current as of 06 March 2017)

García-Pérez E, Gutiérrez-Uribe AJ, García-Lara S (2012) Luteolin content and antioxidant activity in micropropagated plants of Poliomintha glabrescens (Gray). Plant Cell Tiss Organ Cult 108:521-527. https://doi.org/10.1007/s11240-011-0055-z

George P, Manuel J (2013) Low cost tissue culture technology for the regeneration of some economically important plants for developing countries. Int J Agric Environ Biotechnol 6:703-711

Georgiev V, Ilieva M, Bley T, Pavlov A (2008) Betalain production in plant in vitro systems. Acta Physiol Plant 30:581-593. https:// doi.org/10.1007/s11738-008-0170-6

Georgiev M, Weber J, Maciuk A (2009) Bioprocessing of plant cell cultures for mass production of targeted compounds. Appl Microbiol Biotechnol 83:809-823. https://doi.org/10.1007/s0025 3-009-2049-x

Georgiev MI, Agostini E, Ludwig-Muller J, Xu J (2012) Genetically transformed roots: from plant disease to biotechnological resource. Trends Biotechnol 30:528-537. https://doi. org/10.1016/j.tibtech.2012.07.001

Giri A, Narasu ML (2000) Production of podophyllotoxin from Podophyllum hexandrum: a potential natural product for clinically useful anticancer drugs. Cytotechnology 3:17-26

Gleba YY, Tusé D, Giritch A (2014) Plant viral vectors for delivery by agrobacterium. Curr Top Microbiol Immunol 375:155-192. https://doi.org/10.1007/82_2013_352

Goel MK, Kukreja AK, Khanuja SP (2007) Cost-effective approaches fon in vitro mass propagation of Rauwolfia serpentina Benth. Ex Kurz. Asian J Plant Sci 6:957-961

Golle DP, Reiniger LR, Curti AR, León EA (2012) Estabelecimento e desenvolvimento in vitro de Eugenia involucrata DC.: influência do tipo de explante e do meio nutritivo. Ciência Florestal 22:207-214

Govindaraju S, Arulselvi PI (2016) Effect of cytokinin combined elicitors (L-phenylalanine, salicylic acid and chitosan) on in vitro propagation, secondary metabolites and molecular characterization of medicinal herb-Coleus aromaticus Benth (L). J Saudi Soc Agric Sci. https://doi.org/10.1016/j.jssas.2016.11.001 (in Press)

Grzegorczyk-Karolak I, Kuźma $Ł$, Wysokińska H (2015) The effect of cytokinins on shoot proliferation, secondary metabolite production and antioxidant potential in shoot cultures of Scutellaria alpina. Plant Cell Tissue Organ Cult 122:699-708. https://doi. org/10.1007/s11240-015-0804-5

Grzegorczyk-Karolak I, Kuźma Ł, Skała E, Kiss A (2018) Hairy root cultures of Salvia viridis $L$. for production of polyphenolic compounds. Ind Crops Prod 117:235-244. https://doi.org/10.1016/j. indcrop.2018.03.014

Guillon S, Tremouillaux-Guiller J, Pati PK, Rideau M, Ganetet P (2006) Harnessing the potential of hairy roots: dawn of a new era. Trends Biotechnol 24:403-409. https://doi.org/10.1016/j. tibtech.2006.07.002

Gupta P, Sharma S, Saxena S (2016) Effect of abiotic stress on growth parameters and steviol glycoside content in Stevia rebaudiana (Bertoni) raised in vitro. J Appl Res Med Aromat Plants 3:160167. https://doi.org/10.1016/j.jarmap.2016.03.004

Gyulai G, Mester Z, Kiss J, Szemán L, Heszky L, Idnurm A (2003) Somaclone breeding of reed canarygrass (Phalaris arundinacea L). Grass Forage Sci 58:210-215. https://doi.org/10.104 6/j.1365-2494.2003.00372.x 
Haberlandt G (1902) Culturversuche mit isolierten PFlanzellen. Sitzungsber Akad Wiss Wien Math Nat 111:69-91

Hayden CA, Streatfield SJ, Lamphear BJ, Fake GM, Keener TK, Walker JH, Clements JD, Turner DD, Tizard IR, Howard JA (2012) Bioencapsulation of the hepatitis B surface antigen and its use as an effective oral immunogen. Vaccine 30:2937-2942. https://doi.org/10.1016/j.vaccine.2012.02.072

Hayden CA, Smith EM, Turner DD, Keener TK, Wong JC, Walker JH, Tizard IR, Jimenez-Flores R, Howard JA (2014) Supercritical fluid extraction provides an enhancement to the immune response for orally-delivered hepatitis B surface antigen. Vaccine 32:1240-1246. https://doi.org/10.1016/j.vaccine.2014.01.037

Hayta S, Bayraktar M, Baykan erel S, Gurel A (2017) Direct plant regeneration from different explants through micropropagation and determination of secondary metabolites in the critically endangered endemic Rhaponticoides mykalea. Plant Biosyst Int J Deal Asp Plant Biol 151:20-28. https://doi.org/10.1080/11263 504.2015.1057267

Ho TT, Lee KJ, Lee JD, Bhushan S, Paek KY, Park SY (2017) Adventitious root culture of Polygonum multiflorum for phenolic compounds and its pilot-scale production in $500 \mathrm{~L}$-tank. Plant Cell Tissue Organ Cult 130:167-181. https://doi.org/10.1007/s1124 0-017-1212-9

Hu J, Gao X, Liu J, Xie C, Li J (2008) Plant regeneration from petiole callus of Amorphophallus albus and analysis of somaclonal variation of regenerated plants by RAPD and ISSR markers. Bot Stud 49:189-197

Huang TK, McDonald KA (2012) Bioreactor systems for in vitro production of foreign proteins using plant cell cultures. Biotechnol Adv 30:398-409. https://doi.org/10.1016/j.biotechadv .2011.07.016

Huang B, Lin H, Yan C, Qiu H, Qiu L, Yu R (2014) Optimal inductive and cultural conditions of Polygonum multiflorum transgenic hairy roots mediated with Agrobacterium rhizogenes R1601 and an analysis of their anthraquinone constituents. Pharmacogn Mag 10:77-82. https://doi.org/10.4103/0973-1296.126671

Hussain S, Fareed S, Ansari S, Rahman A, Ahmad IZ, Saeed M (2012) Current approaches toward production of secondary plant metabolites. J Pharm Bioallied Sci 4:10-20. https://doi. org/10.4103/0975-7406.92725

Jamwal K, Bhattacharya S, Puri S (2018) Plant growth regulator mediated consequences of secondary metabolites in medicinal plants. J Appl Res Med Aromat Plants. https://doi.org/10.1016/j.jarma p.2017.12.003 (in Press)

Jang S-H, Yu J-Y, Lee EK, Lim MJ, Hong NJ, Oh IS, T-h Kang, E-m So, Jin YW, Jin Y-S, Jeong Y-S, Jeong H-S, Lee J-C, Jang Y-S (2012) In vitro anti-oxidant and anti-inflammatory activities of cambial meristematic cells established from Ginko biloba L. J Med Plant Res 6:3048-3058. https://doi.org/10.5897/JMPR1 1.1784

Jeong QT, Park DH, Ryu HW, Hwang B, Woo JC, Kim D, Kim SW (2005) Production of antioxidant compounds by culture of Panax ginseng C.A. Meyer hairy roots. Appl Biochem Biotechnol 121(1):1147-1157

Juan-jie Z, Yue-sheng Y, Meng-fei L, Shu-qi L, Yi T, Han-bin C, Xiao-yang C (2017) An efficient micropropagation protocol for direct organogenesis from leaf explants of an economically valuable plant, drumstick (Moringa oleifera Lam.). Ind Crops Prod 103:59-63. https://doi.org/10.1016/j.indcrop.2017.03.028

Karalija E, Ćavar Zeljković S, Tarkowski P, Muratović E, Parić A (2017) The effect of cytokinins on growth, phenolics, antioxidant and antimicrobial potential in liquid agitated shoot cultures of Knautia sarajevensis. Plant Cell Tissue Organ Cult 131:347-357. https://doi.org/10.1007/s11240-017-1288-2
Karuppusamy S (2009) A review on trends in production of secondary metabolites from higher plants by in vitro tissue, organ and cell cultures. J Med Plants Res 3:1222-1239

Kaul S, Das S, Srivastava PS (2013) Micropropagation of Ajuga bracteosa, a medicinal herb. Physiol Mol Biol Plants 19:289-296. https://doi.org/10.1007/s12298-012-0161-3

Kaur C, Kapoor HC (2001) Antioxidants in fruits and vegetables - the millennium's health. Int J Food Sci Tech 36:703-725. https://doi. org/10.1111/j.1365-2621.2001.00513.x

Kim DI, Pedersen H, Chin CK (1991) Stimulation of berberine production in Thalictrum rugosum suspension cultures in response to addition of cupric sulfate. Biotechnol Lett 13:213-216. https:// doi.org/10.1007/BF01025820

Kirakosyan A, Cseke LJ, Kaufman PB (2009) The use of plant cell biotechnology for the production of phytochemicals. In: Kirakosyan A, Kaufman PB (eds) Recent advances in plant biotechnology, 1st edn. Springer, New York, pp 15-33. https://doi. org/10.1007/978-1-4419-0194-1_2

Klee H, Horsch R, Rogers S (1987) Agrobacterium-mediated plant transformation and its further applications to plant biology. Annu rev Plant Physiol 38:467-486. https://doi.org/10.1128/ MMBR.67.1.16-37.2003

Kobayashi Y, Fukui H, Tabata M (1987) An immobilized cell culture system for berberine production by Thalictrum minus cells. Plant Cell Rep 6:185-186

Kodym A, Zapata-Arias FJ (1999) Natural light as an alternative light source for the in vitro culture of banana (Musa acuminata cv. 'Grande Naine'). Plant Cell Tissue Organ Cult 55:141-145. https ://doi.org/10.1023/A:1006119114107

Kodym A, Zapata-Arias FJ (2001) Low-cost alternatives for the micropropagation of banana. Plant Cell Tissue Organ Cult 66:67-71. https://doi.org/10.1023/A:1010661521438

Kodym A, Hollenthoner S, Zapata-Arias FJ (2001) Cost reduction in the micropropagation of banana by using tubular skylights as source for natural lighting. In vitro Cell Dev Biol Plant 37:237242. https://doi.org/10.1007/s11627-001-0042-x

Kolewe ME, Gaurav V, Roberts SC (2008) Pharmaceutically active natural product synthesis and supply via plnat cell culture technology. Mol Pharm 5:243-256. https://doi.org/10.1021/mp7001494

Korkina LG, Mayer W, de Luca C (2017) Meristem plant cells as a sustainable source of redox actives for skin rejuvenation. Biomolecules 7:1-22. https://doi.org/10.3390/biom7020040

Kun-Hua W, Lin-Xuan L, Young-Cai W, Mei-Ying W, Cui L, JianHua M (2013) Tissue culture of Sophora tonkinenss Gapnep. and its quality evaluation. Pharmacogn Mag 9:323-330. https://doi. org/10.4103/0973-1296.117828

Lajayer BA, Ghorbanpour M, Nikabadi S (2017) Heavy metals in contaminated enviroment: destiny of secondary metabolite biosynthesis, oxidative status and phytoextraction in medicinal plants. Ecotoxicol Environ Saf 145:377-390. https://doi.org/10.1016/j. ecoenv.2017.07.035

Lakshmi PS, Verma D, Yang X, Lloyd B, Daniell H (2013) Low cost tuberculosis vaccine antigens in capsules: expression in chloroplasts, bio-encapsulation, stability amd functional evaluation in vitro. PLoS One 8:e54708. https://doi.org/10.1371/journ al.pone. 0054708

Larkin PJ, Scowcroft WR (1981) Somaclonal variation: a novel source of variability from cell cultures for plant improvement. Theor Appl Genet 60:197-214. https://doi.org/10.1007/BF02342540

Lee EK, Jin YW, Park JH, Yoo YM, Hong SM, Amir R, Yan Z, Kwon E, Elfick A, Thomilinson S, Halbritter F, Waibel T, Yun BW, Loake GJ (2010) Culture cambial meristematic cells as a source of plant natural products. Nat Biotechnol 28:1213-1217. https:// doi.org/10.1038/nbt.1693

Leibniz Gemeinschaft (2018) Catalogue of plant cell lines. Retrieved April 2, 2018, from Leibniz-Institut DSMZ-Deutsche 
Sammlung von Mikroorganismen und Zellkulturen GmbH: https ://www.dsmz.de/catalogues/catalogue-plant-cell-lines.html

Li Z, Liu Z-B, Xing A, Moon BP, Koellhoffer JP, Huang L, Ward RT, Clifton E, Falco SC, Cigan AM (2015) Cas9-Guide RNA directed genome editing in soybean. Plant Physiol 169:960-970. https://doi.org/10.1104/pp.15.00783

Liu H, Wang X, Wang D, Zou Z, Liang Z (2011) Effect of drought stress on growth and accumulation of active constituents in Salvia miltiorrhiza Bunge. Ind Crops Prod 33:146-151. https://doi. org/10.1016/j.indcrop.2010.09.006

Lubbe A, Verpoorte R (2011) Cultivation of medicinal and aromatic plants for specialty industrial materials. Ind Crop Prod 34:785801. https://doi.org/10.1016/j.indcrop.2011.01.019

Maleki M, Ghorbanpour M, Kariman K (2017) Physiological and antioxidative responses of medicinal plants exposed to heavy metals stress. Plant Gene 11:247-254. https://doi.org/10.1016/j.plgen e.2017.04.006

Martin M (2002) Predatory prokaryotes: an emerging research opportunity. J Mol Miobiol Biotechnol 4:467-477

Martínez-Estrada E, Caamal-Velázquez JH, Salina Ruíz J, Bello-Bello JJ (2017) Assessment of somaclonal variation during sugarcane micropropagation in temporary inmersion bioreactors by intersimple sequence repeat (ISSR) markers. In vitro cell Dev Biol Plant 53:553-560

Martins JP, Pasqual M, Martins AD, Ribeira SF (2015) Effects of salts and sucrose concentrations on in vitro propagation of Billbergia zebrina (Herbert) Lindley (Bromeliaceae). Aust J Crop Sci 9:85

Methora S, Goel MK, Kukreja AK, Mishra BN (2007) Efficiency of liquid culture systems over conventional micropropagation: a progress towards commercialization. Afr J Biotechnol 6:1484-1492

Moon SH, Mistry B, Kim HD, Pandurangan M (2017) Antioxidant and anticancer potential of bioactive compounds following UV-C light-induced plant cambium meristematic cell cultures. Ind Crops Prod 109:762-772. https://doi.org/10.1016/j.inder op.2017.09.024

Morales-Rubio ME, Espinosa-Leal C, Garza-Padrón RA (2016) Cultivo de tejidos vegetales y su aplicación en productos naturales. In: Rivas-Morales C, Oranday-Cardenas MA, Verde-Star MJ (eds) Investigación en plantas de importancia médica, 1st edn. OmniaScience, Barcelona, pp 351-410. https://doi.org/10.3926/ oms.315

Mora-Pale M, Sanchez-Rodriguez SP, Linhardt RJ, Dordick JS, Koffas MA (2014) Biochemical strategies for enhancing the in vitro production of natural poducts with pharmaceutical potential. Curr Opin Biotechnol 25:86-94. https://doi.org/10.1016/j.copbi o.2013.09.009

Mulabagal V, Tsay H-S (2004) Plant cell cultures-an alternative and efficient source for the production of biologically important secondary metabolites. Int J Appl Sci Eng 2:29-48

Muranaka T, Ohkawa H, Yamada Y (1993) Continuous production of scopolamine by a culture of Duboisia leichhardtii hairy root clone in a bioreactor system. Appl Microbiol Biotechnol 40:219-223

Murthy HN, Lee EJ, Paek KY (2014) Production of secondary metabolites from cell and organ cultures: strategies and approaches for biomass improvement and metabolite accumulation. Plant Cell Tissue Organ Cult 118:1-16. https://doi.org/10.1007/s1124 0-014-0467-7

Nagella P, Murthy HN (2010) Establishment of cell suspension cultures of Withania somnifera for the production of withanolide A. Bioresour Technol 101:6735-6739. https://doi.org/10.1016/j. biortech.2010.03.078

Nam J, Matthysse AG, Gelvin SB (1997) Differences in susceptibility of Arabidopsis ecotypes to crown gall disease may result from a deficiency in T-DNA integration. Plant Cell 9:317-333. https ://doi.org/10.1105/tpc.9.3.317
Namdeo AG (2007) Plant cell elicitation for production of secondary metabolites: a review. Pharmacog Rev 1:69-79

Nogueira M, Enfissi EM, Almeida J, Fraser PD (2018) Creating plant molecular factories for industrial and nutritional isoprenoid production. Curr Opin Biotechnol 40:80-87. https://doi. org/10.1016/j.copbio.2017.08.002

Ochoa-Villarreal M, Howat S, Hong S, Jang MO, Jin YW, Lee EK, Loake GJ (2016) Plant cell culture strategies for the production of natural products. BMB Rep 49:149-158. https://doi. org/10.5483/BMBRep.2016.49.3.264

Palacio L, Cantero JJ, Cusidó R, Goleniowski M (2011) Phenolic compound production by Larrea divaricata Cav. plant cell cultures and effect of precursor feeding. Process Biochem 46:418-422. https://doi.org/10.1016/j.procbio.2010.08.029

Palombi M, Damiano C (2002) Comparison between RAPD and SSR molecular markers in detecting genetic variation in kiwifruit (Actinidia deliciosa A. Chev). Plant Cell Rep 20:1061-1066. https://doi.org/10.1007/s00299-001-0430-z

Pandey R, Krishnasamy V, Kumaravadivel N, Rajamani K (2014) Establishment of hairy root culture and production of secondary metabolites in Coleus (Coleus forskohlii). J Med Plant Res 8:58-62. https://doi.org/10.5897/JMPR12.1182

Pandino G, Lombardo S, Antonino LM, Ruta C, Mauromicale G (2017) In vitro micropropagation and mycorrhizal treatment influences the polyphenols content profile of globe artichoke under field conditions. Food Res Int 99:385-392. https://doi. org/10.1016/j.foodres.2017.05.037

Parra O, Gallego AM, Urrea A, Rojas LF, Correa C, Atehortúa L (2017) Biochemical precursor effects on the fatty acid production in cell suspension cultures of Theobroma cacao L. Plant Physiol Biochem 111:59-66. https://doi.org/10.1016/j.plaph y.2016.11.013

Pastores GM, Shankar SP, Petakov M, Giraldo P, Rosenbaum H, Amato DJ, Szer J, Chertkoff R, Brill-Almon E, Zimran A (2016) AJH 36-month safety and efficacy results in adult patients with Enzyme replacement therapy with taliglucerase alfa: Gaucher disease previously treated with imiglucerase. Am J Hematol 91:661-665. https://doi.org/10.1002/ajh.24399

Patwardhan B (2005) Ethnopharmacology and drug discovery. J Ethnopharmacol 100:50-52. https://doi.org/10.1016/j. jep.2005.06.006

Pence VC (2011) Evaluating costs for in vitro propagation and preservation of endangered plants. In Vitro Cell Dev Biol Plant 47:176-187. https://doi.org/10.1007/s11627-010-9323-6

Perassolo M, Cardillo AB, Mugas ML, Núñez Montoya SC, Giulietti AM, Rodríguez Talou J (2017) Enhancement of anthraquinone production and release by combination of culture medium selection and methyl jasmonate elicitation in hairy root cultures of Rubia tinctorum. Ind Crops Prod 105:124-132. https ://doi.org/10.1016/j.indcrop.2017.05.010

Pfizer (2014) Pfizer. Retrieved November 15, 2017, from Pfizer and Protalix Biotherapeutics announce FDA approval of pediatric indication for ELELYSO ${ }^{\mathrm{TM}}$ (taliglucerase alfa) for injection, for intravenous use for the treatment of type 1 Gaucher disease: https://www.pfizer.com/news/press-release/press -release-detail/pfizer_and_protalix_biotherapeutics_annou nce_fda_approval_of_pediatric_indication_for_elelyso_talig lucerase_alfa_for_injection_for_intravenous_use_for_the_treat ment_of_type_1_gaucher_disease

Pickens LB, Tang Y, Chooi Y-H (2011) Metabolic engineering for the production of natural products. Annu Rev Chem Biomol Eng 2:211-236. https://doi.org/10.1146/annurev-chembioeng -061010-114209

Pniewski T, Czyz M, Wyrwa K, Bociag P, Krajewski P, Kapusta J (2017) Micropropagation of transgenic lettuce containing HBsAg as a method of mass-scale production of standardised plant 
material for biofarming purposes. Plant Cell Rep 36:49-60. https ://doi.org/10.1007/s00299-016-2056-1

Pogue GP, Vojdani F, Palmer KE, Hiatt E, Hume S, Phelps J, Long L, Bohorova N, Kim D, Pauly M, Velasco J, Whaley K, Zeitlin L, Granger SJ, White E, Bai Y, Haydon H, Bratcher B (2010) Production of pharmaceutical-grade recombinant aprotinin and monoclonal antibody product using plant-based transient expression systems. Plant Biotechnol J 8:638-654

Puente-Garza CA, García-Lara S, Gutiérrez-Uribe JA (2017a) Enhancement of saponins and flavonols by micropropagation of Agave salmiana. Ind Crops Prod 105:225-230. https://doi. org/10.1016/j.indcrop.2017.05.014

Puente-Garza CA, Meza-Miranda C, Ochoa-Martínez D, García-Lara S (2017b) Effect of in vitro drought stress on phenolic acids, flavonols, saponins and antioxidant activity in Agave salmiana. Plant Physiol Biochem 115:400-407. https://doi.org/10.1016/j. plaphy.2017.04.012

Raduisene J, Karpaviciene B, Stanius Z (2012) Effect of external and internal factors on secondary metabolites accumulation in St. John's wort. Bot Lith 18:101-108. https://doi.org/10.2478/v1027 9-012-0012-8

Rahman M, Rajora O (2001) Microsatellite DNA somaclonal variation in micropropagated trembling aspen (Populus tremuloides). Plant Cell Rep 20:531-536. https://doi.org/10.1007/s002990100365

Rahman ZA, Noor ES, Ali MS, Mirad R, Othman AN (2015) In vitro micropropagation of a valuable medicinal plant Plectranthus amboinicus. Am J Plant Sci 6:1091. https://doi.org/10.4236/ ajps. 2015.68113

Ramakrishna A, Ravishankar GA (2011) Influence of abiotic stress signals on secondary metabolites in plants. Plant Signal Behav 6:1720-1731. https://doi.org/10.4161/psb.6.11.17613

Ramírez-Mosqueda MA, Iglesias-Andreu LG, Ramírez-Madero G, Hernández-Rincón EU (2016) Micropropagation of Stevia rebaudiana Bert. in temporary immersion systems and evaluation of genetic fidelity. S Afr J Bot 106:238-243. https://doi. org/10.1016/j.sajb.2016.07.015

Rani V, Raina SN (2000) Genetic fidelity of organized meristemderived micropropagated plants: a critical reappraisal. In Vitro Cell Dev Biol Plant 36:319-330. https://doi.org/10.1007/s1162 7-000-0059-6

Rao SR, Ravishankar GA (2002) Plant cell cultures: chemical factories of secundary metabolites. Biotechnol Adv 20:101-153. https:// doi.org/10.1016/S0734-9750(02)00007-1

Rathore NS, Rai MK, Phulwaria M, Rathore N, Shekhawat NS (2014) Genetic stability in micropropagated Cleome gynandra revealed by SCoT analysis. Acta Physiol Plant 36:555-559. https://doi. org/10.1007/s11738-013-1429-0

Rizvi MZ, Kukreja AK (2010) In vitro propagation of an endangered medicinal herb Chlorophytum borivilianum Sant. et Fernand. through somatic embryogenesis. Physiol Mol Biol Plants 16:249-257. https://doi.org/10.1007/s12298-010-0026-6

Roberts S, Kolewe M (2010) Plant natural products from cultured multipotent cells. Nat Biotechnol 28:1175-1176. https://doi. org/10.1038/nbt1110-1175

Ron M, Kajala K, Pauluzzi G, Wang D, Reynoso MA, Zumstein K, Garcha J, Winte S, Masson H, Inagaki S, Federici F, Sinha N, Deal RB, Bailey-Serres J, Brady SM (2014) Hary root transformation using Agrobacterium rhizogenes as a tool for exploring cell type-specific gene expression and function using tomato as a model. Plant Physiol 166:455-469. https://doi.org/10.1104/ pp.114.239392

Sack M, Rademacher T, Spiegel H, Boes A, Hellwig S, Drossard J, Stoger E, Fischer R (2015) From gene to harvest: insights into upstream process development for the GMP production of a monoclonal antibody in transgenic tobacco plants. Plant Biotechnol J 13:1094-1105. https://doi.org/10.1111/pbi.12438
Sahu J, Sahu RK (2013) A review on low cost methods for in vitro micropropagation of plant through tissue culture technique. UK J Pharm Biosci 1:38-41. https://doi.org/10.20510/ukjpb/1/ i1/91115

Saito K, Kanehira T, Horimoto M, Moritome N, Komamine A (1993) Biosynthesis of carthamin in florets and cultured cells of Carthamus tinctorius. Biol Plant 35:537

Sakamoto K, Kumiko I, Sawamura K, Hajiro K, Asada Y, Yoshikawa T et al (1994) Anthocyanin production in cultured cells of Aralia cordata Thunb. Plant Cell Tissue Organ Cult 36:21-26

Saranya Krishnan SR, Siril EA (2018) Elicitor mediated adventitious root culture for the large-scale production of anthraquinones from Oldenlandia umbellata L. Ind Crops Prod 114:173-179. https:// doi.org/10.1016/j.indcrop.2018.01.069

Sarasan V, Kite GC, Sileshi GW, Stevenson PC (2011) Applications of phytochemical and in vitro techniques for reducing overharvesting of medicinal and pesticidal plants and generating income for the rural poor. Plant Cell Rep 30:1163-1172. https:// doi.org/10.1007/s00299-011-1047-5

Sharma M, Sharma A, Kumar A, Basu SK (2011) Enhancement of secondary metabolites in cultured plant cells through stress stimulus. Am J Plant Physiol 6:50-71. https://doi.org/10.3923/ ajpp.2011.50.71

Shekhawat MS, Kannan N, Manokari M (2015) In vitro propagation of traditional medicinal and dye yielding plant Morinda coreia Buch.-Ham. S Afr J Bot 100:43-50. https://doi.org/10.1016/j. sajb.2015.05.018

Shilpa K, Varun K, Lakshmi BS (2010) An alternate method of natural drug production: eliciting secondary metabolite production using plant cell culture. J Plant Sci 5:222-247. https://doi.org/10.3923/ jps.2010.222.247

Singh SR, Dalal S, Singh R, Dhawan AK, Kalia K (2013) Evaluation of genetic fidelity of in vitro raised plants of Dendrocalamus asper (Schult. \& Schult. F.) Backer ex K. Heyne using DNA-based markers. Acta Physiol Plant 35:419-430. https://doi.org/10.1007/ s11738-012-1084-x

Singh A, Jani K, Kumari P, Agarwal PK (2015) Effect of $\mathrm{MgCl}_{2}$ and double con- centration of Murashige and Skoog medium on in vitro plantlet and root cultures generation in halophytic grasswort Salicornia brachiata. Plant Cell Tissue Organ Cult 129:501-510. https://doi.org/10.1007/s11240-014-0622-1

Sivanandhan G, Selvaraj N, Ganapathi A, Manickavasagam M (2014) Enhanced biosynthesis of withanolides by elicitation and precursor feeding in cell suspension culture of Withania somnifera (L.) Dunal in Shake-Flask culture and bioreactor. PLoS One 9:e104005. https://doi.org/10.1371/journal.pone.0104005

Smetanska I (2008) Production of secondary metabolites using plant cell cultures. Adv Biochem Eng Biotechnol 111:187-228. https ://doi.org/10.1007/10_2008_10

Sorace M, de Faria RT, Júnior CV, Gomes GP, Barbosa CM, Vieira FG, Lopes da Silva G, Assari Takahashi LS, Aparecida Schnitzer J (2008) In vitro growth of Oncidium baueri (Orchidaceae) at different macronutrients and sucrose concentrations. Semin Cienc Agrar 29:775-782

Srivastava S, Srivastava AK (2007) Hairy root culture for mass-production of high-value secondary metabolites. Crit Rev Biotechnol 27:29-43. https://doi.org/10.1080/07388550601173918

Srivastava S, Srivastava AK (2014) Effect of elicitors and precursors on Azadirachtin production in hairy root culture of Azadirachta indica. Appl Biochem Biotechnol 172:2286-2297. https://doi. org/10.1007/s12010-013-0664-6

Stanišić M, Raspor M, Ninković S, Milošević S, Ćalić D, Bohanec B, Trifunovića M, Petrića M, Subotića A, Jevremovića S (2015) Clonal fidelity of Iris sibirica plants regenerated by somatic embryogenesis and organogenesis in leaf-base culture-RAPD 
and flow cytometer analyses. S Afr J Bot 96:42-52. https://doi. org/10.1016/j.sajb.2014.10.014

Su WW, Lee K-T (2007) Plant cell and hairy root cultures-process characteristics, products, and applications. In: Yang S-T (ed) Bioprocessing for value-added products from renewable resources. Elsevier B.V, Boston, pp 263-292

Su J, Zhu L, Sherman A, Wang X, Kamesh A, Norikane JH, Streatfield SJ, Herzog RW, Daniell H (2015) Low cost industrial production of coagulation factor IX bioencapsulated in lettuce cells for oral tolerance induction in hemophilia B. Biomaterials 70:84-93. https://doi.org/10.1016/j.biomaterials.2015.08.004

Tari I, Kiss G, Deer AK, Csiszar J, Erdei L, Galle A, Gémes K, Horváth F, Poór P, Szepesi Á, Simon LM (2010) Salicylic acid increased aldose reductase activity and sorbitol accumulation in tomato plants under salt stress. Biol Plant 54:677-683. https ://doi.org/10.1007/s10535-010-0120-1

Thakore D, Srivastava AK (2017) Production of biopesticide azadirachtin using plant cell and hairy root cultures. Eng Life Sci 17:997-1005. https://doi.org/10.1002/elsc.201700012

Thiruvengadam M, Praveen N, Kim EH, Kim SH, Chung IM (2014) Production of anthraquinones, phenolic compounds and biological activities from hairy roots cultures of Polygonum multiflorum Thunb. Protoplasma 251:555-566. https://doi. org/10.1007/s00709-013-0554-3

Thomas DR, Penney CA, Majumder A, Walmsley AM (2011) Evolution of plant-made pharmaceuticals. Int J Mol Sci 12:32203236. https://doi.org/10.3390/ijms 12053220

Thorpe T (2007) History of plant tissue culture. J Mol Microb Biotechnol 37:169-180

Tusé D, Tu T, McDonald KA (2014) Manufacturing economics of plant-made biologics: case studies in therapeutic and industrial enzymes. BioMol Res Int 2014:1-16. https://doi. org/10.1155/2014/256135

Van Eck J (2018) Genome editing and plant transformation of solanaceous food crops. Curr Opin Biotechnol 49:35-41. https:// doi.org/10.1016/j.copbio.2017.07.012

Varshney A, Lakshmikumaran M, Srivastava PS, Dhawan V (2001) Establishment of genetic fidelity of in vitro-raised Lilium bulblets through RAPD markers. In Vitro Cell Dev Biol Plant 37:227-231. https://doi.org/10.1007/s11627-001-0040-z

Verma N, Shukla S (2015) Impact of various factors responsible for fluctuation in plant secondary metabolites. J Appl Res Med Aromat Plants 2:105-113. https://doi.org/10.1016/j.jarma p.2015.09.002

Verma P, Mathur AK, Jain SP, Mathur A (2012) In vitro conservation of twenty-three overexploited medicinal plants belonging to the Indian Sub Continent. Sci World J 2012:1-10. https://doi. org/10.1100/2012/929650

Verpoorte R, van der Heijden R, Memelink J (2000) Engineering the plant cell factory for secondary metabolite production. Transgen Res 9:323-343. https://doi.org/10.1023/A:1008966404981

Verpoorte R, Contin A, Memelink J (2002) Biotechnology for the production of plant secondary metabolites. Phytochem Rev $1: 13-25$

Verslues PE, Agarwal M, Katiyar-Agarwal S, Zhu J, Zhu JK (2006) Methods and concepts in quantifying resistance to drought, salt and freezing, abiotic stresses that affect plant water status. Plant $\mathbf{J}$ 45:523-539. https://doi.org/10.1111/j.1365-313X.2005.02593.x

Vinterhalter B, Krstić-Milošević D, Janković T, Pljevljakušić D, Ninković S, Smigocki A, Vinterhalter D (2015) Gentiana dinarica Beck. Hairy root cultures and evaluation of factors affecting growth and xanthone production. Plant Cell Tissue Organ Cult 121:667-679

Voytas DF (2013) Plant genome engineering with sequence-specificnucleases. Annu Rev Plant Biol 64:327-350. https://doi. org/10.1146/annurev-arplant-042811-105552
Voytas DF, Gao C (2014) Precision genome engineering and agriculture: oportunities and regulatory challenges. PLoS Biol 12:1-6. https://doi.org/10.1371/journal.pbio.1001877

Wagner H, Stuppner H, Schåfer W, Zenk M (1988) Immunologically active polysaccharides of Echinacea purpurea cell cultures. Phytochemistry 119:126

Wang CH, Zheng LP, Tian H, Wang JW (2016) Synergistic effects of ultraviolet-B and methyl jasmonate on tanshinone biosynthesis in Salvia miltiorrhiza hairy roots. J Photochem Photobiol B 159:93-100. https://doi.org/10.1016/j.jphotobiol.2016.01.012

Wani SH, Sah SK (2014) Biotechnology and abiotic stress tolerance in rice. J Rice Res 2:e105. https://doi.org/10.4172/jrr.1000e105

Wani SH, Kumar V, Shriram V, Sah SK (2016) Phytohormones and their metabolic engineering for abiotic stress tolerance in crop plants. Crop J 4:162-176. https://doi.org/10.1016/j.cj.2016.01.010

Wawrosch C, Schwaiger S, Stuppner H, Kopp B (2014) Lignan formation in hairy root cultures of Edelweiss (Leontopodium nivale spp. alpinum (Cass.) Greuter). Fitoterapia 97:219-223. https:// doi.org/10.1016/j.fitote.2014.06.008

Wendt T, Doohan F, Mullins E (2012) Production of Phytophtora infestance resistance potato (Solanum tuberosum) utilizing Ensifer adhearence OV 14. Trans Res 21:567-578. https://doi. org/10.1007/s11248-011-9553-3

Wilson SA, Roberts SC (2012) Recent advances towards development and commercialization of plant cell culture processes for synthesis of biomolecules. Plant Biotechnol J 10:249-268. https://doi. org/10.1111/j.1467-7652.2011.00664

Xu JF, Dolan MC, Medrano G, Cramer CL, Weathers PJ (2012) Green factory: plants as bioproduction platforms for recombinant proteins. Biotechnol Adv 30:1171-1184. https://doi.org/10.1016/j. biotechadv.2011.08.020

Yamamoto Y (1988) Tissue cultures of Euphorbia species. In: Hanover JW, Keathley DE, Wilson CM, Kuny G (eds) Genetic manipulation of woody plants. Springer, New York, pp 365-376

Yao J, Weng Y, Dickey A, Wang KY (2015) Plants as factories for human pharmaceuticals applications and challenges. Int J Mol Sci 16:28549-28565. https://doi.org/10.3390/ijms161226122

Yun UW, Yan Z, Amir R, Hong S, Jin YW, Lee EK, Loake GJ (2012) Plant natural products: history, limitations and the potential of cambial meristematic cells. Biotechnol Genet Eng Rev 28:47-59. https://doi.org/10.5661/bger-28-47

Zeitlin L, Prettitt J, Scully C, Bohorova N, Kim D, Pauly M, Hiatt A, Ngo L, Steinkellner H, Whaley KJ, Olinger GG (2011) Enhanced potency of a fucose-free monoclonal antibody being developed as an Ebola virus immunoprotectant. Proc Natl Acad Sci USA 108:20690-20694. https://doi.org/10.1073/pnas.1108360108

Zenk MH, Juenger M (2007) Evolution and current status of the phytochemistry of nitrogenous compounds. Phytochemistry 68:27572772. https://doi.org/10.1016/j.phytochem.2007.07.009

Zhi-lin Y, Chuan-chao D, Lian-qing C (2007) Regulation and accumulation of secondary metabolites in plant-fungus symbiotic system. Afr J Biotechnol 6:1266-1271. https://doi.org/10.4314/ ajb.v6i11.57436

Zhou G, Wang Y, Zhai S, Ge F, Liu Z, Dai Y, Yuan S, Hou JY (2013) Biodegradation of the neonocotinoid insecticide thiamethoxam by nitrogen-fixin and plany-growth-promoting rizobacterium Ensifer adhaerens strain TMX-23. Appl Microbiol Biotechnol 97:4065-4074. https://doi.org/10.1007/s00253-012-4638-3

Zhu C, Bortesi L, Baysal C, Twyman RM, Fischer R, Capell T, Schillberg S, Christou P (2017) Characteristics of genome editing mutations in cereal crops. Trends Plant Sci 22:38-52. https:// doi.org/10.1016/j.tplants.2016.08.009

Zuniga-Soto E, Mullins E, Didicova B (2015) Ensifer-mediated transformation: an efficient non-Agrobacterium protocol for the genetic modification of rice. Springerplus 4:1-10. https://doi. org/10.1186/s40064-015-1369-9 